\title{
Hanford Ground-Water Data Base Management Guide and User's Manual
}

\author{
P. J. Mitchell \\ R. S. Argo \\ S. L. Bradymire \\ C. A. Newbill
}

May 1985

Prepared for the U.S. Department of Energy under Contract DE-AC06-76RLO 1830

Pacific Northwest Laboratory Operated for the U.S. Department of Energy by Battelle Memorial Institute 


\title{
DISCLAIMER
}

This report was prepared as an account of work sponsored by an agency of the United States Government. Neither the United States Government nor any agency thereof, nor any of their employees, makes any warranty, express or implied, or assumes any legal liability or responsibility for the accuracy, completeness, or usefulness of any information, apparatus, product, or process disclosed, or represents that its use would not infringe privately owned rights. Reference herein to any specific commercial product, process, or service by trade name, trademark, manufacturer, or otherwise, does not necessarily constitute or imply its endorsement, recommendation, or favoring by the United States Government or any agency thereof. The views and opinions of authors expressed herein do not necessarily state or reflect those of the United States Government or any agency thereof.

\author{
PACIFIC NORTHWEST LABORATORY \\ operated by \\ BATTELLE \\ for the \\ UNITED STATES DEPARTMENT OF ENERGY \\ under Contract DE-AC06-76RLO 1830
}

\begin{tabular}{|c|c|}
\hline inted & of America \\
\hline & \\
\hline National Tech & ation Service \\
\hline United States & of Commerce \\
\hline 5285 & oad \\
\hline Spring & 22161 \\
\hline & \\
\hline & \\
\hline & \\
\hline & Price \\
\hline Pages & Codes \\
\hline $001-025$ & $\mathrm{~A} 02$ \\
\hline $026-050$ & $\mathrm{~A} 03$ \\
\hline $051-075$ & $\mathrm{~A} 04$ \\
\hline $076-100$ & $A 05$ \\
\hline $101-125$ & $A 06$ \\
\hline $126-150$ & $A 07$ \\
\hline $151-175$ & $A D B$ \\
\hline $176-200$ & $\mathrm{~A} 09$ \\
\hline $201-225$ & A010 \\
\hline $226-250$ & A011 \\
\hline $251-275$ & A012 \\
\hline $276-300$ & A013 \\
\hline
\end{tabular}


HANFORD GROUND-WATER OATA BASE MANAGEMENT GUIDE

AND USER'S MANUAL

P. J. Mitchell

R. S. Argo

S. L. Bradymire

C. A. Newbill

May 1985

Prepared for the U.S. Department of Energy under Contract DE-ACD6-76RLO 1830

Pacific Northwest Laboratory

Richland, Washington 99352 


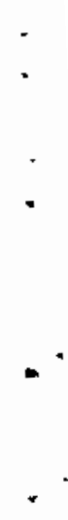




\section{PREFACE}

This document is divided into two main parts. Part I is a management guide for data base maintenance. This includes all data entry and modification activities. Part II is the user's manual for all data retrieval activities. Appendix $C$, which is not referred to in the body of the text, describes a separate data base for ground water modeling which will contain artificial recharge rates to the ground from Hanford Site disposal activities. 


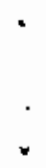

$-$

$+$

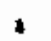

. 


\section{ACKNOWLEDGMENTS}

The authors would like to acknowledge D. R. Friedrichs and D. W. Damschen who performed the majority of the programming of CIRMIS codes prior to 1982. A. E. Reisenauer reviewed this report and provided many helpful comments. The work has been funded through the Richland Operations office of the Department of Energy. 
SUMMARY

This management guide and user's manual is a working document for the computerized Hanford Ground-Water Data Base maintained by the Geosciences Research and Engineering Department at Pacific Northwest Laboratory for the Hanford Ground-water Surveillance Program. The progran is managed by the occupational and Environmental Protection Department for the U.S. Department of Energy. The data base is maintained to provide rapid access to data that are routinely collected from ground-water monitoring wells at the Hanford site. The data include water levels, sample analyses, geologic descriptions and well construction information for over 3000 existing or destroyed wells. These data are used to monitor water quality and for the evaluation of ground-water flow and pollutant transport problems.

The management guide gives instructions for maintenance of the data base on the Digital Equipment Corporation PDP $11 / 70$ Computer using the CIRMIS (Comprehensive Information Retrieval and Model Input Sequence) data base management software developed at Pacific Northwest Laboratory. Maintenance activities include inserting, modifying and deleting data, making back-up copies of the data base, and generating tables for annual monitoring reports.

The user's guide inciudes instructions for running prograrns to retrieve the data in the form of listings or graphical plots. 



\section{CONTENTS}

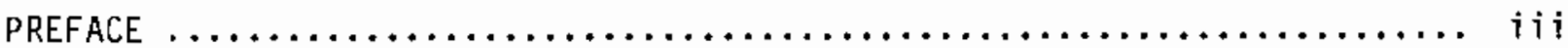

ACKNOWLEDGMENTS $\ldots \ldots \ldots \ldots \ldots \ldots \ldots \ldots \ldots \ldots \ldots \ldots \ldots \ldots \ldots \ldots \ldots \ldots \ldots$

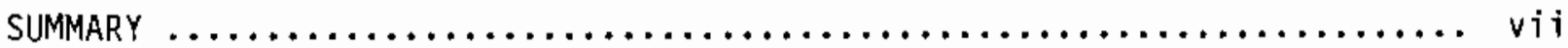

PARt I. Management gUIDE $\ldots \ldots \ldots \ldots \ldots \ldots \ldots \ldots \ldots \ldots \ldots \ldots \ldots \ldots \ldots \ldots \ldots \ldots$

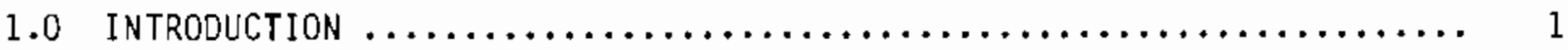

2.0 HEADER INFORMATION ON HELLS $\ldots \ldots \ldots \ldots \ldots \ldots \ldots \ldots \ldots \ldots \ldots \ldots \ldots \ldots \ldots \ldots$

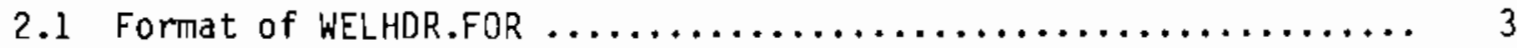

2.2 Program WELCOMPAR for Updating WELLDR.FOR $\ldots \ldots \ldots \ldots \ldots \ldots \ldots$

2.3 Program CONVRT for Coordinate Conversion $\ldots \ldots \ldots \ldots \ldots \ldots \ldots$

3.0 ADDING WELLS WITH PROGRAM WHDRADD AND EMAGEN $\ldots \ldots \ldots \ldots \ldots \ldots \ldots \ldots$

4.0 ORGANIZATION OF WELLNAM DIRECT ACCESS FILE $\ldots \ldots \ldots \ldots \ldots \ldots \ldots \ldots \ldots$

5.0 ROUtine data base maintenance PROGRams $\ldots \ldots \ldots \ldots \ldots \ldots \ldots \ldots \ldots \ldots \ldots \ldots$

5.1 Checking New Analytical Data for Outliers and

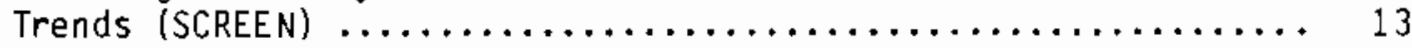

5.2 Inserting, Modifying and Deleting Analytical,

Hydrograph and Temperature Data with the Program CRMSED ....... 15

5.2 .1 Control Record Format $\ldots \ldots \ldots \ldots \ldots \ldots \ldots \ldots \ldots \ldots \ldots \ldots \ldots$

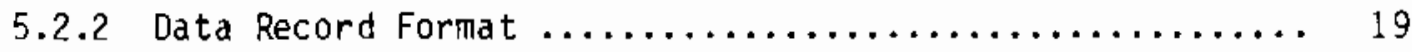

Example 1: Insert Analytical Data (EMA

Codes for Well Names and

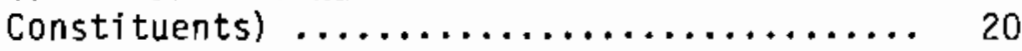

Example 2: Insert Analytical Data (Hanford Designations for Well Names and Constituents) ..................... 23

Example 3: Modify Analytical Values (Hanford Designations for Well Names and Constituents) 
Example 4: Delete Analytical Values (Hanford Designations for Wel 1 Names and

Constituents) ...................... 24

Example 5: Insert Hydrograph Data (Hanford Designations for Well Names) ............ 25

Example 6: Modify Hydrograph Data (Hanford Designations for Well Names)........... 27

Example 7: Delete Hydrograph Data (Hanford Designations for WeTl Names) ........... 28

Example 8: Insert Temperature Data (Hanford Designations or EMA Codes for Well Names and Constituents) ............... 28

Example 9: Modify Temperature Data (Hanford Designation or EMA Code for Well Names and Constituents) .................... 29

Example 10: Delete Temperature Data (Hanford Designation or EMA Codes for Well Names

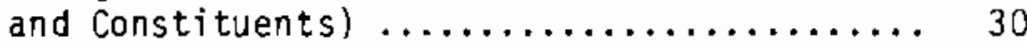

5.3 Generating Geologic Data $\ldots \ldots \ldots \ldots \ldots \ldots \ldots \ldots \ldots \ldots \ldots \ldots \ldots \ldots$

5.3.1 Formatted Well Log Input File ................ 32

5.3 .2 Programs for Checking Input File $\ldots \ldots \ldots \ldots \ldots \ldots \ldots . \ldots . \ldots$

5.3.3 Entering Well Log Data with WLGGEN Program .......... 39

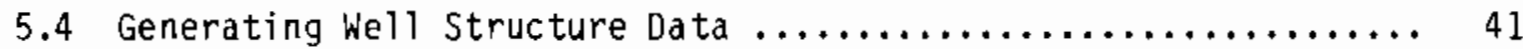

6.0 QUARTERLY BACK-UP ACTIVITIES $\ldots \ldots \ldots \ldots \ldots \ldots \ldots \ldots \ldots \ldots \ldots \ldots \ldots \ldots \ldots \ldots$

6.1 CIRMIS Formatted output Program (CRMFOR) $\ldots \ldots \ldots \ldots \ldots \ldots \ldots . .47$

6.2 Program WELNPTS for Data Summaries $\ldots \ldots \ldots \ldots \ldots \ldots \ldots \ldots \ldots . \ldots$

7.0 WELL DATA LISTING FOR THE HANFORD WELLS REPORT $\ldots \ldots \ldots \ldots \ldots \ldots \ldots \ldots$

7.1 Format of Input File to Program WELDOC $\ldots \ldots \ldots \ldots \ldots \ldots \ldots \ldots .51$

7.2 Creating Listings with Program WELDOC $\ldots \ldots \ldots \ldots \ldots \ldots \ldots \ldots$

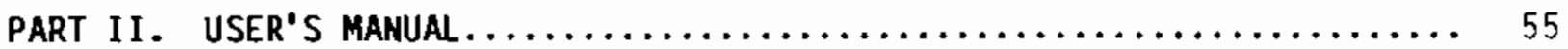

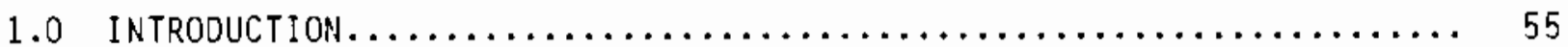




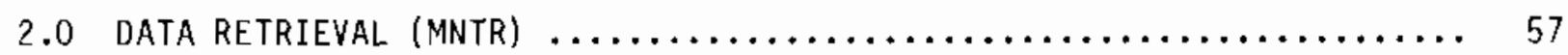

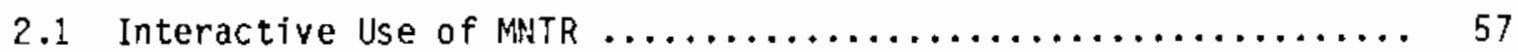

2.2 Command File for MnTR $\ldots \ldots \ldots \ldots \ldots \ldots \ldots \ldots \ldots \ldots \ldots \ldots \ldots, 60$

3.0 Creating Tables for Annual Reports $\ldots \ldots \ldots \ldots \ldots \ldots \ldots \ldots \ldots \ldots . \ldots \ldots \ldots$

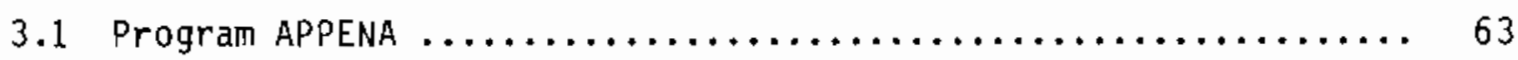

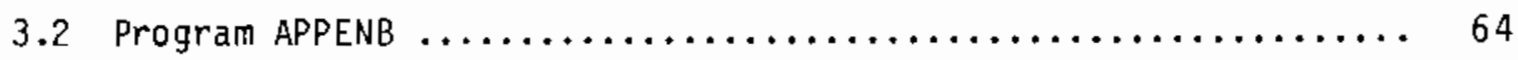

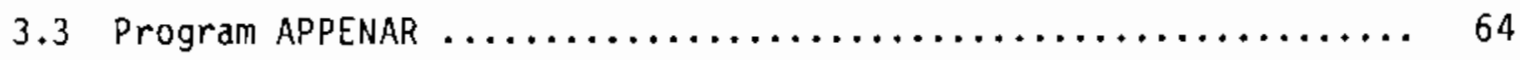

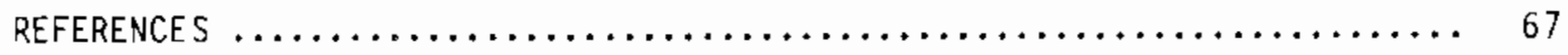

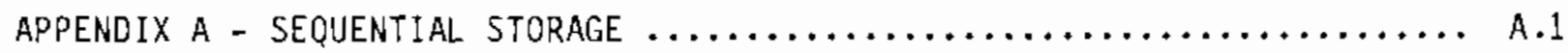

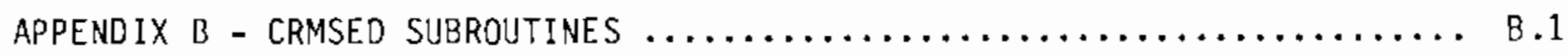

APPENDIX $C$ - DISPOSAL/WITHDRAWAL DATA BASE $\ldots \ldots \ldots \ldots \ldots \ldots \ldots \ldots \ldots \ldots \ldots \ldots \ldots \ldots \ldots$ 
、 
PART 1. MANAGEMENT GUIDE 


\subsection{INTRODUCTION}

CIRMIS (Comprehensive Information Retrieval and Model Input Sequence) is a data base management system developed at Pacific Northwest Laboratory (PNL) by Dennis Friedrichs in 1974. The software was written to store and retrieve ground-water monitoring-well water level measurements, sample analytical data and other types of information for the Hanford site in eastern Washington (Friedrichs and Argo 1980). The PNL data base employing CIRMIS is called the Hanford Groundwater Data Base. CIRMIS is the tool, or set of computer programs, used to input and retrieve data from the data base. The programs of CIRMIS, therefore, define the way the data base is organized and the way data are input and retrieved.

CIRMIS stores data in direct access files (developed for the Digital Equipment Corporation POP $11 / 70$ computer) called "File-Q" files. "Blocks" of data are stored or retrieved for one well at a time, each "block" containing 256 integer or 128 real values. In brder to store or retrieve data from the data base, the location in each file the desired block of data must be known. The files are called "direct access" because blocks in the files can be accessed directly when the block number is known. This differs from "sequential" files whose data can only be accessed in numerical sequence. Retrieval of data from direct access files is faster than from sequential files when the desired data are scattered throughout the file, as is the case with large data bases.

Some of the terms used in this report are briefly defined here:

$$
\begin{aligned}
& \text { File-Q file = random or direct access file } \\
& 1 \text { character = } 1 \text { byte } \\
& 1 \text { byte }=8 \text { bits } \\
& 1 \text { integer word }=2 \text { bytes } \\
& 1 \text { real word }=2 \text { integer words } \\
& 1 \mathrm{disc} \text { sector }=256 \text { integer words }=1 \text { block. }
\end{aligned}
$$

CIRMIS stores data in a hierarchical fashion by well and then by type of data (water level, analytical, etc.). In other words, to store or retrieve data, the user must input the well name and type of data desired for that 
we11. Given the well name, CIRMIS reads "header" information for that well from a File-Q file called WELLHDR. WELLHDR is also a directory of which data types are available for each well and where the data are located. Having read the header information from WELLHDR and having found where the desired data are located, CIRMIS goes to the appropriate file to store or retrieve the data contained at the file location specified in WELLHDR.

"Header" information for a given well can be found only when it is known where in WELLHDR to look, since WELLHDR is a direct access file. To aid in locating desired information in WELLHOR, a File-Q "look-up" file for wells. called WELLNAM was created. WELLNAM contains a list of all well names, the location of each name in the list corresponding with the block number at which information in WELLHDR can be found for that well. Therefore, the paths to data are through WELLNAM, then through WELLHDR, and then to the appropriate data files. For example, to find hydrograph information for well 62020 , CIRMIS finds "6 2020 " in the WELLNAM file and reads data from the same location in WELLHDR. If the data exists, it is then found in a file called FRMTHYD (the direct access file containing hydrograph data). 


\subsection{HEADER INFORMATION ON WELLS}

The CIRMIS system is suited for use with ground-water data that are based on wells. The WELLNAM and WELLHDR File-Q files are created with the program WHDRGEN. WHDRGEN reads the wells in sequential order from a formatted file called WELHDR.FOR and stores the well names in the direct access file WELLNAM. Each well's header parameters are then stored in another direct access file, WELLHDR, which contains a 256 integer-word disk sector for each well.

The direct access file CTMHDR, which is generated by WHDRGEN, contains addresses for all the sample analytical data for each well. The addresses indicate where analytical data are located in the FRMTCTM direct access file for a given wel1. The CTMHDR file was developed because the WELLHDR file is not large enough to store all avajlable addresses for analytical data.

The direct access file UPDATEHDR is generated by WHDRGEN. This file is a single block long and contains information on the starting location for adding contaminant, hydrograph, temperature, and well log data to existing files. WHDRGEN also creates a formatted file called WELHDRNEW.SEQ. This file contains a listing of well names with associated block addresses in WELLHDR.

WELHDRNEW. SEQ is used when all wells in the data base are to be searched for information because it provides a rapid access to the WELLHDR file. Examples of programs using WELHDRNEW.SEQ (or a subset of it) are CRMFOR (See Section 5.2 .3 ), APPENA, and APPENB (described in Section 3.0 of Part II.)

\subsection{FORMAT OF WELHDR.FOR}

The WELHDR.FOR file is created using the system editor. It contains a list of well names with location coordinates and casing elevations.

A brief example is shown below:

WELLHDR . FOR

$1 \quad B 3 \quad 1 \quad P_{N} 71800 . W 79830.439 .79$

$\begin{array}{lllllll}6 & 24 & 24 & P N & 50000 . W & 2000 . & 442.0\end{array}$

The first line of the file is read but ignored, so it can contain the name of the file or some other descriptive phrase. 
The format of WELHDR.FOR is:

\begin{tabular}{|c|c|c|c|c|c|}
\hline $\begin{array}{c}\text { Current } \\
\text { Well Name } \\
\end{array}$ & $\begin{array}{l}\text { Rea } 1 \text { Coor } \\
(x)\end{array}$ & $\begin{array}{r}\text { nates } \\
(Y)\end{array}$ & $\begin{array}{c}\text { Casing } \\
\text { Elevation }\end{array}$ & $\begin{array}{l}\text { Changed } \\
\text { Well Name }\end{array}$ & $\begin{array}{l}\text { Previous } \\
\text { Wel? Name }\end{array}$ \\
\hline A & $x, 2$ & A1, F7. & F8.2 & $5 X, 12 A 1$ & $5 X, 12 A T$ \\
\hline
\end{tabular}

Normally the weli name, coordinates, and casing elevation are known from regional documentation. In most cases, the coordinates (which may be in the form of township and range, latitude and longitude, or even in some Tocal coordinate system) must be converted to Plant, Richland, or Hanford coordinates that are stored in the data base. The coordinates in the regional documentation are converted to Plant coordinates with the CONVRT program (see Section 2.3).

\subsection{PROGRAM WELCOMPAR FOR UPOATING WELHDR.FOR}

Information for WELHDR.FOR on coordinates and casing elevations for new or existing wells and name changes for wells are received from Hanford field personnel. A formatted file called DCUMNT.DAT is a master fjle of all Hanford site wells constructed from pre-Hanford Works days to the present. Upon request, DCUMNT.DAT is used as input to the program WELDOC to create DCUMNT.LST, which is in a readable table-format for inclusion in the Hanford Wells Book document. (DCUMNT.DAT and DCUMNT.LST are renamed (e.g., OCUMNT84) and stored on tape each time they are updated.)

Program WELCOMPAR is run to show the differences between DCUMNT.DAT and WELHDR.FOR so that both fjles are as complete as possible. Occasionally, new wells will be added to WELHDR.FOR when hydrograph or analytical data are received before the well appears in OCUMNT.DAT. As a rule, all data on wells in OCUMNT.DAT supersede those in WELHDR.FOR. WELCOMPAR compares well nalies, coordinates, and casing elevations in DCUMNT.DAT with WELHDR.FOR and lists unmatched wells in the output file UNMATCHED.DAT. The list of wells in WELHOR.FOR should be in the same order as the wells in DCUMNT.DAT. (If they are not in the same order, some wells that are in both files will be listed in the UNMATCHED.OAT file). All unmatched wells should be examined and, when possible, WELHDR.FOR should be changed to agree with DCUMNT.DAT. However, 
DCUMNT.DAT should never be changed to agree with WELHDR.FOR because coordinates and casing elevations may have been estimated for WELHDR. FOR before survey data were available.

\subsection{PROGRAM CONVRT FOR COORDINATE CONVERSION}

The CONVRT program can be used to convert 1) Lambert coordinates to PIant coordinates, or 2) Plant, Hanford, and Richland coordinates to Lambert (State) coordinates and longitude-latitude values.

1) Example input file of Lambert coordinates to be converted to Plant coordinates:

$\begin{array}{llll}6111 & 24 & 516240.03 \mathrm{~N} 2271040.00 \mathrm{E}\end{array}$

$6113 \quad 38 \quad 518204.09 \mathrm{~N} 2257035.25 \mathrm{E}$

$611460 \quad 519147.59 \mathrm{~N} \mathrm{2235032.50 \textrm {E }}$

6 HAN $1458165.88 \mathrm{~N} 2281948.25 \mathrm{E}$

6 HAN 2457473.84 N 2281546.00E

Format: $\quad 1 \times, 12 \mathrm{Al}, 1 \times, \mathrm{F} 10.0, \mathrm{~A} 1,1 \times, \mathrm{Fl} 0.0, \mathrm{~A} 1$

The following is the interactive stream for running CONVRT (user responses are underlined):

PDS >>RUN DB1:CONVRT

ENTER NAME OF INPUT FILE (3OA1) > COORDS. INP

ENTER NAME OF OUTPUT FILE (30A1) > COORDS.OUT

\section{SELECT:}

(0) Lambert to Plant coordinates

(1) Plant, etc. coordinates to Lambert to Longitude-Latitude

-

TTOOA - - STOP

The output file for the above example is: 


\begin{tabular}{|c|c|c|c|c|}
\hline WELL & \multicolumn{2}{|c|}{ LAMBERT COORDINATES } & \multicolumn{2}{|c|}{ PLANT COORDINATES } \\
\hline $\begin{array}{lll}6 & 111 & 24\end{array}$ & $516240 . \mathrm{N}$ & $2271040 . \mathrm{E}$ & $111000 . \mathrm{N}$ & $24000 . \mathrm{W}$ \\
\hline $\begin{array}{lll}6 & 113 & 38\end{array}$ & 518204.N & 2257035.E & $113000 . \mathrm{N}$ & $38000 . \mathrm{W}$ \\
\hline $6114 \quad 60$ & 519148.N & 2235033.E & $114000 . \mathrm{N}$ & $60000 . \mathrm{W}$ \\
\hline 6 HAN 1 & $458166 . N$ & 2281948.E & 52898. N & $13241 . W$ \\
\hline 6 HAN & $457474 . \mathrm{N}$ & $2281546 . \mathrm{E}$ & $52207 . \mathrm{N}$ & $13645 . W$ \\
\hline
\end{tabular}

2) Example input file of Plant coordinates to be converted to Lambert coordinates:

611124 PN 111000.W 24000. 699.14

$611338 \quad \mathrm{PN} 113000 . \mathrm{W} 38000.732 .01$

611460 PN $114000 . W 60000$. 787.50

6 HAN 1 PN 52898.W 13241. 392.82

6 HAN 2 PN 52207.W 13645. 394.97

Note: the $P$ must be replaced with a $H$ or $R$ for Hanford or Richland coordinates, respectively).

FORMAT: $\quad 1 X, 12 A 1,1 X, A 1, A 1, F 7.0,1 X, A 1, F 7.0, F 8.0$

The interactive stream for running the other option in CONVRT is: PDS $>$ RUN DB1:CONYRT

ENTER NAME OF INPUT FILE $(30 A 1)>$ DB1:COORDS.INP

ENTER NAME OF OUTPUT FILE (3OA1) > OB1:COORDS.OUT SELECT:

(0) LAMBERT TO PLANT COORDINATES

(1) PLANT, ETC. COORDINATES TO LAMBERT TO LONGitUdE-LATITUDE

$\frac{1}{\text { TTOOA }}$ - STOP

The output file for the above example is: 


\begin{tabular}{|c|c|c|c|c|c|}
\hline WELL $N$ & AME & PLANT COORD INATES & LAMBERT COORDINATES & LONG I TUDE & LAT I TUDE \\
\hline 6111 & 24 & PN111000.W24000. LN & 516240.03 E 2271040.00 & 19.25 .7 .86 & 46.44 .38 .03 \\
\hline 6113 & 38 & PN113000, $38000 . \mathrm{LN}$ & 518204.09 E 2257035.25 & 119.28 .28 .58 & 46. 44.59 .29 \\
\hline 6114 & 60 & PN1 14000. W 60000, LN & 519147.59 E 2235032.50 & 119.33 .44 .38 & $46.45,0.00$ \\
\hline 6 HAN & 1 & PN 52898. W 13241. LN & 458165.88 E $228194 B .25$ & 119.22 .43 .10 & 46.35 .3 .32 \\
\hline 6 HAN & 2 & 听 52207.W 13645. LN & 457473.84 E 2281546.00 & $119 \quad 22.49 .00$ & 46.34 .56 .54 \\
\hline
\end{tabular}




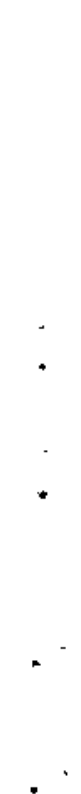




\subsection{ADDING WELLS WITH PROGRAM WHDRADD AND EMAGEN}

The "Changed Well Name" and "Previous Well Name" fields of WELHDR.FOR (described in section 2.1) are not used by WHDRGEN, but are used by WHDRAOD . The WHDRADD program adds new wells to the data base while maintaining the existing wells and associated data. WHDRADD requires use of the input file WELHDR.FOR and a mounted "backup" disk in addition to the original disk containing the data base. WHDRADD is run interactively so that disk numbers can be entered accordingly. This process updates the WELLHOR, WELLNAM, UPDATEHDR, and CTMHDR direct access files on the backup disk. At this point the backup disk requires the renainder of data base direct access files, EMACODE, FRMTHYD, FRMTTMP, FRMTWST, FRMTWLG, FRMTVTT, FRMTCTM, GRADX, GRADY, WELL299E, WELL299W, WELL699, WELL399, to be a complete copy of the data base. Furthermore, the updated WELLHOR, WELLNAM, PDATEHDR and CTMHDR files must be copied back to the original disk to include the added wells.

WHDRADD creates a new file called WELHDRUPD.FOR which now contains the old well name in the "Previous Well Name" field, and leaves the "Changed Well Name" field blank. After new wells have been added, or old well names changed, the WELHDRUPD.FOR file should be renamed WELHDR.FOR, for input to a subsequent run of WHDRADD or WELCOMPAR.

EMAGEN must also be run when the new wells added to WELHDR.FOR are those which will receive analytical or temperature data identified by well EMA (Environmental Monitoring Analysis) code (an alternate well designation system used for Hanford wells). A file called EMACODE.SRC riust be updated and input to program EMAGEN. Each record of this file contains a Hanford well designation in columns 3-14 (6A2) and its corresponding EMA code in columns 2023 (I4). The records are arranged in ascending order by EMA code. EMAGEN packs these records (32 to a disk sector) and outputs them to the FILE-0 structured file EMACODE. It is this file that the CRMSED subroutines use in converting from EMA code to the Hanford well designation assigned to the well in the field. 


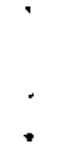

.

$\cdot$

.

.

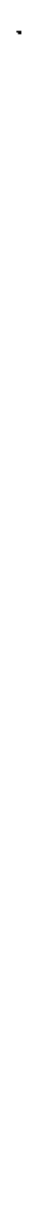




\subsection{ORGANIZATION OF WELLNAM DIRECT ACCESS FILE}

In order to access data for a given well, that well's name must first be be located in WELLNAM. WELLNAM, like WELLHDR, is a direct access file from which data are retrieved a block at a time. Each biock retrieved from WELLNAM contains 512 bytes or characters. The names of all the wells in the data base are stored in WELLNAM, 42 names per block. This is because the type of well designations used on the Hanford site, for which CIRMIS was initially designed, requires 12 characters per well designation. With such designations, only 42 well names can be stored in a 512 -byte block $(12 \times 42=504$ characters with 8 bytes left over at the end of the block).

Hanford well designations usually indicate the particular area in which the wells are located. The areas are called 199, 299E, 299W, 399, 499, 699, 1199, and 3099. The first two characters of the Hanford well name indicate in which of these areas the well is located. The corresponding first two characters of Hanford well names are $1,2 \mathrm{E}, 2 \mathrm{~W}, 3,4,6,11$, and 30 . Retrieval efficiency over a random listing of well names is improved because the wells are grouped in WELLNAM according to the area in which the well is located. A set number of biocks are allocated for each area and the number of blocks depend on the current and expected number of wells drilled in that area. therefore, retrieval of data for a well in a specific area onty requires a search in the correct group of blocks.

Table 1 shows the current storage allocations for the data base. The first two characters of the well names (Well Prefix) indicates the areas in which the wells are located. The block range shows which blocks are allocated in WELLNAM for each area. The number of blocks allocated for each area (No. of Blocks) and the current number of well names stored for each area (Wells Stored) are also shown. As of September 1984, and the maximum number of well names that can be stored, given the number of blocks allocated for each area, is listed (Max. No. of Wells). 
TABLE 1. Hanford Ground-Water Data Base Storage Al location

\begin{tabular}{|c|c|c|c|c|}
\hline $\begin{array}{c}\text { Well } \\
\text { Prefix }\end{array}$ & $\begin{array}{l}\text { Block } \\
\text { Range } \\
\end{array}$ & $\begin{array}{l}\text { No. of } \\
\text { Blocks } \\
\end{array}$ & $\begin{array}{l}\text { Wells } \\
\text { Stored }\end{array}$ & $\begin{array}{l}\text { Max. No. } \\
\text { of Wells }\end{array}$ \\
\hline 1 & 0 to 4 & 5 & 105 & 210 \\
\hline $2 E$ & 5 to 34 & 30 & 555 & 1,260 \\
\hline $2 W$ & 35 to 69 & 35 & 801 & 1,470 \\
\hline 3 & 70 to 74 & 5 & 37 & 210 \\
\hline 6 & 75 to 124 & 50 & 781 & 2,100 \\
\hline 11 & 125 to 129 & 5 & 105 & 210 \\
\hline 30 & 130 to 131 & 2 & 9 & 84 \\
\hline \multirow[t]{2}{*}{4} & 132 to 134 & 3 & 3 & 126 \\
\hline & Totals & 135 & 2,396 & 5,670 \\
\hline
\end{tabular}

These well prefixes, which have matching starting blocks in WELLHDR, are programmed into the generator programs WHDRGEN and WHDRADD, and the retrieval subroutine RTVHOR. RTVHDR is the subroutine used by all the programs accessing the data base. WHDRGEN and WHDRADD store the well names of a given area sequentially in the blocks allocated for that area. When data for a given well are requested, RTVHDR starts at the starting block of the appropriate area and searches sequentially through each block of WELLNAM until the desired well name is found or the end of the group of blocks allocated for that area is encountered. If the desired well name is not found, a message is written to the screen during use of the retrieval programs. 


\subsection{ROUTINE DATA BASE MAINTENANCE PROGRAMS}

Normally, only two programs are run on a regular basis to check input data and insert, modify or delete data. These are SCREEN and CRMSED. Basically, SCREEN is used to check new analytical data for possible "outliers" (bad or inconsistent values) or other problems prior to entering the data into the data base. SCREEN also predicts when a given constituent is expected to exceed maximum permissible limits or drop below minimum detection limits according to the historical trend in values. CRMSED is the program used to enter, delete, or change data in the data base, which includes sample analytical, hydrograph. (ground-water elevations), and temperature data. (Sections 5.3 and 5.4 describe input and modification of geologic and well construction data, respectively).

\subsection{CHECKING NEW ANALYTICAL DATA FOR OUTLIERS AND TRENDS (SCREEN)}

SCREEN is run to check water quality input data for possible "outliers", or new data points that are not consistent with the trend of the previous five years of measurements. SCREEN al so compares the trend in the measured data with the U.S. Department of Energy (DOE) or the U.S. Environmental Protection Agency (EPA) maximum permissible limits to estimate when concentrations at a given well will exceed water quality standards or drop below laboratory detection limits.

Prior to running SCREEN on data files received from the laboratory an "INSERT" line must be added to the beginning of the data file and an "END" line added to the end. These additional lines, which serve as control records for CRMSED, are more fully explained in Section 5.2.

A sample input file is shown below:

INSERT 11830302

KI1882 108830302

$0.14 \mathrm{E}+050.00 \mathrm{E}+000.00 \mathrm{E}+00$

KI1882 115830302

$0.46 \mathrm{E}+01 \quad 0.00 \mathrm{E}+000.00 \mathrm{E}+00$

KI1884 108830302

$0.49 E+05 \quad 0.00 E+000.00 E+0 D$

END 
This simplified input file does not show data in fields which are not read by SCREEN, although they are pertinent to the laboratory.

The first line, "INSERT", is read, and only IOTYPE (see Section 5.2.1) is used by SCREEN. The last line, "END", indicates the end of the data set. The lines in between, containing actual data supplied by the laboratories, are described in detail in Section 5.2.2. The following is the interative stream for running SCREEN (responses by the user are underlined):

RUN DB1:SCREEN

ENTER FILE-Q DISC UNIT (IE. DP1,DBO) > DB1:

ENTER CRITERIA FILE (30A1) > CRIT.DOE

ENTER INPUT FILE (30A1) > DB1:UST840113. INP

SELECT:

( $\langle C R\rangle$ ) REGULAR INPUT ANALYSIS

(1) ANALYZE LAST 20 PTS PRIOR TO GIVEN OATE

$\frac{\langle C r\rangle}{\text { TTOOA }}=$ STOP

The output file, SCREEN.OUT, gives information on the input data. A new data point is considered an "outlier" if it lies outside the two-sigma envelope of a predicted value for that date. The prediction is made by fitting a straight line through the logarithms of the last 20 points of data for that particular constituent and well. The logarithm of the data values are not used for fitting if any of the last 20 points are zero or negative. The envelope is calculated as 2.09 times the standard deviation of the prediction, corresponding to the $95 \%$ confidence interval for a "student's T" distribution with 20 degrees of freedom. Information on "outliers," or the dates (in YYMMDD format) when maximum permissible or minimum detection limits are expected to be reached, is written to SCREEN.OUT. If a 1 imit is expected to be exceeded after December 31, 1999, the date is written as 991231+. SCREEN.OUT contains the well EMA number, the Hanford well designation, the sample date, the name of the constituent, the constituent EMA number, the Hanford constituent number, the lab measured value for concentration or activity, the minimum detection limit (read from a file such as CRIT.OOE or CRIT.EPA containing DOE and EPA standards, respectively), a "YES" or "NO" indicating whether or not the level 
was less than the detection limit, the upper limit of concentration or activity allowed for that constituent by DOE or EPA, a "YES" or "NO" indicating whether the contaminant level exceeded that 1 imit, and the date the concentration or activity is expected to drop below the detection limit or exceed the maximum permissible limit.

\subsection{INSERTING, MODIFYING AND OELETING ANALYTICAL, HYDROGRAPH AND TEMPERATURE DATA WITH THE PROGRAM CRMSED}

CRMSED provides generating and updating capabilities for the CIRMIS data base direct access files of analytical, hydrograph, or temperature data. The program provides a means for entering new data, deleting incorrect data, and modifying selected data points. The code was written in modular form to facilitate the addition of new data types. Because of the overlay structure, the routines share the same memory, and currently require less than $100 \mathrm{~K}$ of memory to execute. CRMSED initially generates the data base. Regeneration programs are used to restore the data files, if necessary (CRMSED subroutines and regeneration programs are described in Appendix B).

The files used and created by CRMSED are:

\begin{tabular}{|c|c|c|}
\hline Name & Type & Access \\
\hline FILE Q--WELLNAM & RANDOM & READ \\
\hline FILE Q--WELLHOR & RANDOM & READ/WRITE \\
\hline FILE Q--UPDATEHDR & RANDOM & READ/WRITE \\
\hline FILE Q--EMACODE & RANDOM & READ \\
\hline FILE Q--FRMTHYD (HYDROGRAPH DATA FILE) & RANDOM & READ/WRITE \\
\hline FILE Q--FRMTTMP (TEMPERATURE DATA FILE) & RANDOH & READ/WRITE \\
\hline FILE Q--FRMTCTM (ANALYTICAL DATA FILE) & RANDOM & READ/WRITE \\
\hline FILE Q--CTMHDR (ANALYTICAL HEADER FILE) & RANDOM & READ/WRITE \\
\hline CRMSED. INP & FORMATTED & READ \\
\hline CRMSED.RUN & FORMATTED & WRITE \\
\hline
\end{tabular}

The file UPDATEHDR stores the addresses of the next available free sectors of the hydrograph, temperature, and geologic log files so that data can be added to these files. Analytical and temperature data are usually received in 
the correct format on magnetic tape. Hydrograph data, however, requires some processing because it is not usually received in the required feet above mean sea level. Programs for converting data from meters to feet, or from depth to water to feet above sea level, are described in Example 5 of Section 5.2.2.

An input file called CRMSED. INP, for example, must be avajlable to run CRMSED. Files are actually named UST840101. INP or BNW840101. INP to indicate 1) whether the data are from Pacific Northwest Laboratory or U.S. Testing Laboratory and 2) the date of processing with CRMSED. The data file consists of one or more data sets. A data set contains a control record (see Section 5.2.1), data records (described in section 5.2.2), and an END card ("END" in columns 1-3). The control record describes the action to be taken on the data (INSERT, CHANGE, or DELETE), the data type (hydrograph, analytical or temperature), and the form of the data (Hanford designations or EMA codes for wells and constituents). It also contains the current date for descriptive purposes and for checking by CRMSED to ensure that no dates in the input data are later than the current date. Any number of data sets may follow one another in the same CRMSED. INP fi]e. Each data set must be set apart, however, with its own control record and END card.

The current CIRMIS FILE-Q data base disc must be mounted (although it is usually mounted) on the appropriate disc drive after logging into the PDP $11 / 70$ computer as follows (a)1 user responses are underlined and (cr) means carriage return):

$$
\begin{aligned}
\text { PDS }> & \frac{\text { LOGIN CIRMIS (PaSSWORd) }}{\text { PDS }>} \\
\text { MOUNT DBI:SPLITV/CHA }=[D C F, A T C H] & \\
\text { DEVICE } & =\text { DBI: } \\
\text { CLASS } & =\text { FILE } 11 \\
\text { LABEL } & =\text { SPLITV } \\
\text { UIC } & =[1,1] \\
\text { ACCESS } & =[\text { RWED, RWED, RWED, RWED }] \\
\text { CHARAC } & =[D C F, A T C H]
\end{aligned}
$$

PDS》 RUN DB1:CRMSED

ENTER FILE-Q DISC (I.E. DB2 or DB1) DB1 
ENTER NAME OF INPUT FILE

DB1:CRMSED.INP

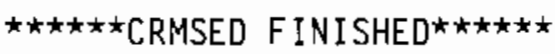

CRMSED reads the data from the indicated input file (CRMSED.INP in this case), locates the appropriate file on the FILE-Q disC, performs the task indicated on the control card (INSERT, DELETE, OR CHANGE) if possible, then writes the card image from CRMSED. INP to a formatted file CRMSED.RUN. If it was not possible to perform the task (well not found, EMA code not found, etc.) an error message is also written to CRMSED.RUN. When CRMSED is finished, the file CRMSED. RUN must be 1 isted on the printer and examined for error messages. Errors, if any, must be corrected in a new file, and CRMSED must be rerun. When a successful run has been made, the input and output files are copied to tape and stored with a directory listing of the tape.

\subsubsection{Control Record Format}

The first line of each input data set is a control record that indicates the action to be taken (INSERT, DELETE, or CHANGE), the type of data (hydrograph, analytical or temperature), and the form of the well names and constituent codes (Hanford designations or EMA codes). The following are some examples of control records, an explanation of the different parts of the control record, and the control record format.

Control Record Examples:

INSERT 11840210

DELETE 10840210

CHANGE 00840210

Control Card Format: ( $A 6,1 X, I 1,1 X, I 1,1 X, F 6.0$ )

Control Record Explanation:

Columns 1-6 (A6) Update Action:

INSERT : Insert new data to existing data files.

DELETE : Delete the following data from existing data files.

CHANGE : The following data are to replace existing data in the files. 
Column 8 (I1)

IDTYPE : Indicates the type of data to be acted upon.

Currently IDTYPE can take on three values:

$=0$ : hydrograph (ground water elevation data)

$=1$ : analytical data

$=2$ : temperature data

Column 10 (I1)

IOTYPE : Indicates the type of wel1 and analysis designations (used only for analytical and temperature data).

$=0$ : Hanford designations will be used in the data set:

le.g., $2 \mathrm{~W} 231$ for a well,

1 through 32 for contaminants)

$=1$ : EMA codes:

(e.g., 1300 designating the Hanford well $2 \mathrm{~W} 231$,

115 designating the constituent nitrate).

Columns 12-17 (F6.0) Current Date: Used to check input dates (to be certain they do not exceed the current date) and to record the date of processing within the file.

The Hanford well designations and corresponding EMA codes for wells can be found in the file EMACODE.SRC. The Hanford designations and corresponding EMA codes for constituents are listed below:

\begin{tabular}{|c|c|c|c|}
\hline $\begin{array}{r}\text { Hanford } \\
\text { Constituent } \\
\end{array}$ & No. & $\begin{array}{l}\text { Constituent } \\
\text { Name } \\
\end{array}$ & $\begin{aligned} & \text { EMA Code } \\
& \text { for Constituent }\end{aligned}$ \\
\hline 1 & -- & TOTAL ALPHA & 112 \\
\hline 2 & & TOTAL BETA & 111 \\
\hline 3 & -- & TRITIUM & 108 \\
\hline 4 & & NITRATE & 115 \\
\hline 5 & -- & STRONTIUM-90 & 121 \\
\hline 6 & & CESIUM- 137 & 24 \\
\hline 7 & -- & COBALT -60 & 10 \\
\hline 8 & & URANI UM-238 & 104 \\
\hline 9 & -- & PLUTONIUM- 239 & 103 \\
\hline 10 & & RUTHEN I UM- 106 & 34 \\
\hline
\end{tabular}




\begin{tabular}{|c|c|c|c|}
\hline 11 & -- & CHROMIUM +6 & 114 \\
\hline 12 & & FLUORIDE & 26 \\
\hline 13 & -- & MAGNESIUM & 54 \\
\hline 14 & & PU $239 / 240$ & 100 \\
\hline 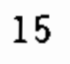 & -- & PU 238 & 102 \\
\hline 16 & & CHLORIDE & 57 \\
\hline 17 & -- & COPPER & 58 \\
\hline 18 & & HARDNESS & 62 \\
\hline 19 & -- & SOLIDS & 63 \\
\hline 2 & & NITRATE ION & 116 \\
\hline \multirow[t]{2}{*}{21} & -- & TOTAL ORGANIC & \\
\hline & & CARBON & 198 \\
\hline 22 & & $\mathrm{PH}$ & 199 \\
\hline 23 & -- & SULFATE & 200 \\
\hline 2 & & SODIUM & 201 \\
\hline 25 & -- & CALCIUM & 202 \\
\hline 26 & & TOTAL GAMMA & 998 \\
\hline 27 & -- & BICARBONATE ION & 188 \\
\hline 28 & & CARBONATE ION & 189 \\
\hline 29 & -- & TOTAL POTASSIUM & 190 \\
\hline \multirow[t]{2}{*}{30} & & SPECIFIC & \\
\hline & & CONDUCTIVITY & 191 \\
\hline & -- & BORON & 192 \\
\hline & & LOW ALPHA & \\
\hline
\end{tabular}

\subsubsection{Data Record Format}

This section illustrates the possible types of data records for CRMSED. The examples given in this section are summarized here:

Example 1: Insert Analytical Data (EMA Codes for Well Names and Constituents)

Example 2: Insert Analytical Data \{Hanford Well Designations\}

Example 3: Modify Analytical Data (Hanford Well Designations) 
Example 4: Delete Analytical Data (Hanford Well Designations)

Example 5: Insert Hydrograph Data (Hanford Well Designations)

Example 6: Modify Hydrograph Data (Hanford Well Designations)

Example 7: Delete Hydrograph Data (Hanford Well Designations)

Example 8: Insert Temperature Data (Ema Codes or Hanford Well Designations)

Example 9: Modify Temperature Data (Ema Codes or Hanford We11 Designations)

Example 10: Delete Hydrograph Data (Ema Codes or Hanford We11 Designations)

Example 1. Insert Analytical Data (EMA Codes for Well Names and Constituents)

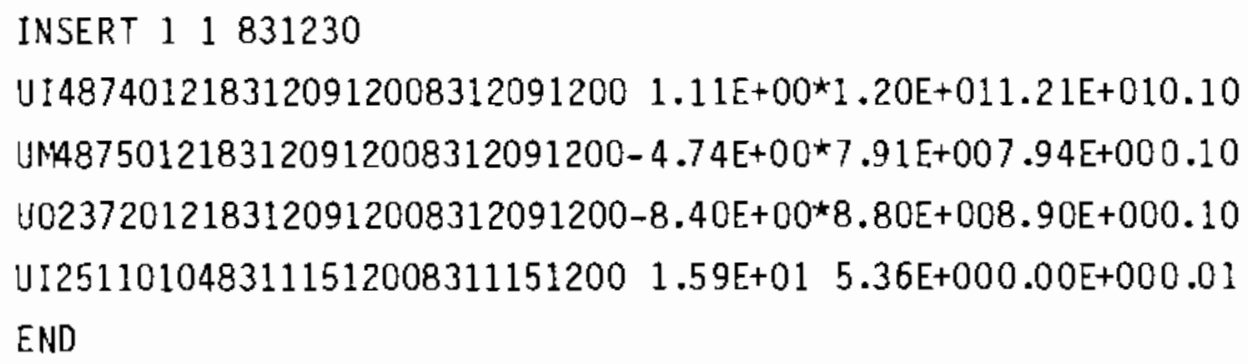

Data Record Format (1X, A1, I4, I1 I3, F6.0,14X,E9.2,1X,2E8.2)

Data Record Explanation:

An explanation of these lines, by column number, is summarized below and described in the following text. (Data fields containing values from the 1 aboratory, but not used or stored by the data base, are not described here.)

Column 1: The Lab Code indicates which laboratory did the analysis. "U" represents the U.S. Testing Laboratory, "K" represents Pacific Northwest Laboratory and "H" represents the laboratory at the HEHF (Hanford Environmental Health Foundation). This information is not stored in the data base. 


$\begin{aligned} \frac{\text { Column \# }}{1} & \text { Description } \\ 2 & \text { Uab Code } \\ 3-6 & \text { EMA Code Action } \\ 8-10 & \text { EMA Code for Constituent } \\ 11-16 & \text { Sample Date (YYMMDD) } \\ 31-39 & \text { Measured Value } \\ 40 & \text { Less Than Flag } \\ 41-48 & \text { Counting Error (for radionuclides only) } \\ 49-56 & \text { Total Propagated Error }\end{aligned}$

Column 2: The update Action indicates the type of action to be taken on the data. The three indicators received, in order of decreasing frequency of occurrence, are :

1) "I" for insert

2) "M" for modification or change, and

3) "D" for deletion of the data point.

Al though this value is not stored in the data base, SCREEN warns the user if the update action is other than an "I." Different data record formats are required for deletions or modifications.

Columns 3-6 (14): The EMA Code indicates the well for which the analysis is made. Each EMA Number corresponds to a Hanford well designation. A typical Hanford well designation is 6241 , indicating a we11 in the 600 Area. The approximate Plant Coordinates are 24,000 feet west and 1000 feet north of the Hanford origin. A sequential listing of EMA numbers with the corresponding Hanford well designations is contained the file EMACODE.SRC.

Columns 8-10 (13): The Constituent Code is an EMA code for the constituent type. EMA numbers for the 32 constituents are scattered between 10 and 998. CIRMIS converts EMA codes to numbers from 1 to 32 for efficiency. A listing of CIRMIS constituent codes with corresponding EMA numbers is presented in Section 5.2.1.

Columns 11-16 (F6.0): The Sample Date is the date the sample was taken in the field. The date is in YYMMDD format, with the year designated first, the 
month second, and the day last, using two numbers for each. For example, June 2, 1984, would be designated 840602. November, 11, 1911, would appear as 111111.

Columns 31-39 (E9.2): The measured value represents the concentration or activity (for radionuclides) of the contaminant as measured by the laboratory. Concentrations are reported in milligrams per liter and activities are reported in pico-curies per liter. The activity values are calculated at U.S. Testing from this equation:

$$
A=\frac{S-B}{E^{\star} Y}
$$

where $A$ is the sample activity in disintegrations per minute (dpm), $S$ is the sample count rate $(\mathrm{cpm}), B$ the background count rate (cpm), E the counter efficiency in counts per disintegration, and $Y$ the procedure recovery (yield). The laboratory converts A to pico-curies per liter for each radionuclide. The elements of the calculation are more fully explained in the internal document distributed by U.S. Testing entitled "Transmission of Error for Radiochemical Analyses." The sample count rate, $S$, in the above equation may be smaller than $B$, the background count rate, and, therefore, the activity is calculated as a negative value. Negative values occur fairly frequently in the analyses sent by the laboratory and are inserted as such.

Column 40: The Less Than Flag in column 40 is not currently stored in the data base.

Columns 41-48 (E8.2): This field contains the Counting Error for radionuclide analyses. According to page 2 of the U.S. Testing internal document, "Transmission of Error for Radiochemical Anatysis," the estimated error in radioactive counting is given by the standard deviation of the count rate, defined as "assuming a poisson distribution, ... the square root of the count rate divided by counting time." The counting error, then, is given by:

$$
E=(\mathrm{cpm} / \mathrm{t}) \star \star 0.5,
$$


where $E$ is the counting error, $c p m$ is the sample count rate, and $T$ is the counting period.

Columns 49-56 (E8.2): The Total Propagated Error is the sum of all the errors involved in the analysis.

Example 2. Insert Analytical Data (Hanford Designations for Well Names and Constituents)

INSERT 10840210

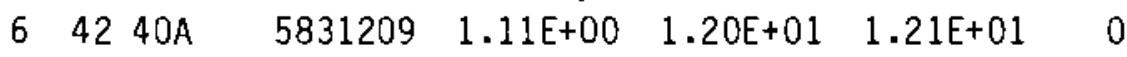

END

Data Record Format $(12 \mathrm{~A} 1,1 \mathrm{X}, \mathrm{I} 2, \mathrm{~F} 6.0,3 \mathrm{E} 10.2, \mathrm{I} 5)$

Data Record Explanation:

\begin{tabular}{|c|c|c|}
\hline Column \# & Example Value & Description \\
\hline $1-12$ & $64240 \mathrm{~A}$ & Hanford Well Designation \\
\hline $14-15$ & 5 & Hanford Constituent Number \\
\hline $16-21$ & 831209 & Date sample was taken \\
\hline $22-31$ & $1.11 E+00$ & Analytical value \\
\hline $32-41$ & $1.20 \mathrm{E}+01$ & Counting error \\
\hline $42-51$ & $1.21 E+01$ & Total propagated error \\
\hline $52-56$ & 0 & Duplicate number \\
\hline
\end{tabular}

Example 3. Modify Analytical Values (Hanford Designations for Well Names and Constituents)

CHANGE 10841001

$\begin{array}{llll}6 \quad 4240 \mathrm{~A} & 5831209\end{array}$

$\begin{array}{llllllll}1.11 E+00 & 1.20 E+01 & 1.21 E+01 & 0 & 2.22 E+00 & 2.40 E+01 & 2.42 E+01 & 0\end{array}$ END 
Data Record Format(12A1,1X, I2,1X,F6.0/2(3E10.2, I5))

Data Record Explanation:

Line 1 : CHANGE card (Described in section 5.2.1.)

Line 2 : Well designation ( $64240 \mathrm{~A}$ ), constituent number ( 5 corresponds to strontium-90), sample date (831209 is December 9, 1983).

Line 3 : Existing data followed by new values desired.

$$
\begin{aligned}
1.11 \mathrm{E}+00 & =\text { existing analytical value } \\
1.20 \mathrm{E}+01 & =\text { existing counting error } \\
1.21 \mathrm{E}+01 & =\text { existing total propagated error } \\
0 & =\text { existing duplicate number (always } 0 \text { ) } \\
2.22 \mathrm{E}+00 & =\text { new analytical value } \\
2.40 \mathrm{E}+01 & =\text { new counting error } \\
2.42 \mathrm{E}+01 & =\text { new total propagated error } \\
0 & =\text { new duplicate number (always } 0 \text { ) }
\end{aligned}
$$

Line 4 : END indicates end of data set

Example 4. Delete Analytical Values (Hanford Designations for Well Names and Constituents)

DELETE 10841001

$\begin{array}{llllll}64240 \mathrm{~A} & 5831209 & 1.11 \mathrm{E}+00 & 1.20 \mathrm{E}+01 & 1.21 \mathrm{E}+01\end{array}$

END

Data Record Format $(12 \mathrm{Al}, 1 \mathrm{X}, \mathrm{I2}, \mathrm{F} 6.0,3 \mathrm{E} 10.3, \mathrm{I5})$ 
Data Record Explanation:

642 40A : Hanford Well Designation.

5 : Constituent Number

831209 : Sample Date

$1.11 \mathrm{E}+00$ : Analytical Value

$1.21 \mathrm{E}+01$ : Counting Error

1.20E+01: Total Propagated Error

Example 5. Insert Hydrograph Data (Hanford Designations for Well Names)

Special Preparation for Data Received as Meters Above Mean Sea Level

(HYOCON)

Water level data for selected wells are received from Rockwell Hanford Operations in a published table twice per year in the form of meters above mean sea level. These values must be converted to feet above mean sea level with the program HYDCON. An input file for all wells in the table must be prepared, as shown below, in an example for one data point:

$5 \quad 59 \quad 56 \quad 830503 \quad 27.96$

Data Record Format $(12 \mathrm{~A} 1,1 \mathrm{X}, 6 \mathrm{~A} 1, \mathrm{~F} 10.0)$

Data Record Explanation:

65956 : Hanford Well Designation

830503 : Date of Measurement (usually at top of data sheet)

27.96 : Water Leve1 in Meters above Mean Sea Leve1

The program may be run as follows when the input file has been created:

PDS> >RUN DB1:HYOCON

ENTER NAME OF HYDROGRAPH INPUT FILE 
DB1: HYDMETER.DAT

OUTPUT FILE WILL BE DB1:HYDMETER.FET

CONVERT ;

(1) METERS TO FEET

(2) FEET TO METERS (not used for input to this data base)

$\underline{1}$

The output file is in the correct format to use with CRMSED for input to the data base, except that a control card must be added to the top of the file (See Section 5.2.1) and an END card must be added to the end of file. The .DAT, .INP, and. RUN (created by CRMSED) files are then copied to tape and the line printer listings of these files are put into a notebook designated for hydrograph data. MNTR is run to check that the data were successfully added to the data base (see Section 2.0 of Part II).

Special Preparation for Data Received as Depths to Water (HYOCOR)

Depth to water table measurements in feet are received from Basalt waste Isolation Program (BWIP) monitoring activities. Depth to water values must be converted to feet above mean sea level by subtracting them from the associated casing elevations for each well as stored in the file WELHDR.FOR. The HYDCOR program performs this task when used as shown below. An example input file called HYD841001.DAT (use current date in the filename) is shown below for one we11:

$6 \quad 42 \quad 12 \mathrm{~A} \quad 841001 \quad 163.03$

Data Record Format $(12 \mathrm{~A} 1,1 \times, \mathrm{F} 6.0, \mathrm{~F} 10.0)$

Data Record Explanation:

642 12A : Hanford Well Designation

841001 : Date of Measurement

163.03 : Depth to water in Feet 
The program is run as follows:

PDS $>$ RUN DB1:HYDCOR

ENTER NAME DF FILE TO BE CONVERTED HYD841001.DAT

YOUR OUTPUT FILE IS HYD841001.INP (INPUT FILE TO CRMSED)

TT16 - STDP

The output file is in the correct format to use with CRMSED for input to the data base, except that a control card must be added to the top of the file (See Section 5.2.1) and an END card must be added to the end of file. The .DAT, .INP, and. RUN files (created by CRMSED) are then copied to tape and the line printer listings of these files are put into a notebook designated for hydrograph data. MNTR is run to check that the data were successfuily added to the data base (see Section 2.0 of Part II).

Files of water level data created from scratch (i.e., not created by running HYOCON or HYDCOR) must be in the following format:

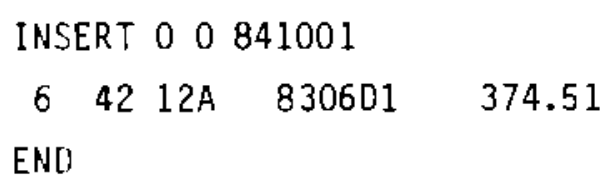

Data Record Format $(12 \mathrm{Al}, 1 \times, \mathrm{F} 6.0, \mathrm{~F} 10.0)$

Data Record Explanation:

642 12A : Hanford Well Designation. 830601 : Date of Measurement 374.51 : Water Level measurement above Mean Sea Level in Feet.

Example 6. Modify Hydrograph Data (Hanford Designation for We11 Names) 
CHANGE 000841001

$\begin{array}{llllll}6 & 42 & 12 A & 830601 & 364.51 & 374.51\end{array}$

END

Data Record Format $(12 A 1,1 \times, F 6.0,2 F 10.0)$

Data Record Explanation:

642 12A : Hanford Well Designation

830601 : Date of Original Measurement

364.51 : Existing Incorrect value

374.51 : New Correct value to Replace old

Example 7. Delete Hydrograph Data (Hanford Designation for Well Names)

DELETE 00841001

$\begin{array}{lllll}6 & 42 & 12 \mathrm{~A} & 830601 & 404.40\end{array}$

END

Data Record Format $(12 \mathrm{~A} 1,1 \mathrm{X}, \mathrm{F} 6.0, \mathrm{~F} 10.0)$

Explanation of Data Record:

$64212 A$ : Hanford Well Designation.

830601 : Date of Measurement

404.40 : Height of Water Table above Mean Sea Level

in Feet.

Example 8. Insert Temperature Data (Hanford Designations or EMA Codes for Well Names and Constituents)

Example with Hanford Well Designation: 
INSERT 20800111

$\begin{array}{lllll}6 & 1 & 18 & 800111 & 17.10\end{array}$

(Well) (Date) (Temperature)

END

Data Record Format for Above Example $(12 A 1,1 \times, F 6.0, F 10.0)$

Example with EMA Code Well Designation :

INSERT 21800111

$4513800111 \quad 17.10$

(EMA \#) (Date) (Temperature)

END

Data Record Format for Above Example (I5,1X,F6.0,F10.0)

Example 9. Modify Temperature Data (Hanford Designation or EMA Code for Well Names and Constituents)

Example with Hanford Well Designation:

CHANGE 20800111

$\begin{array}{llllll}6 & 1 & 18 & 800111 & 16.10 & 17.10\end{array}$

END

Data Record Format for Above Example (12A1,1X,F6.0,2F10.0)

Data Record Explanation:

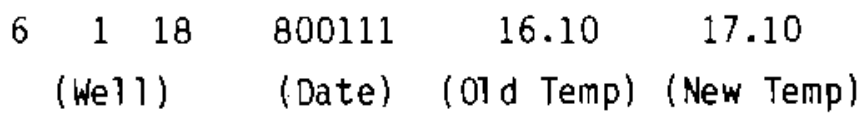

Example with EMA Code Well Designation : 
CHANGE 21800111

$\begin{array}{lll}4513800111 & 16.10 & 17.10\end{array}$

Data Record Format (I5,1X,F6.0,2F10.0)

Data Record Explanation:

$$
\begin{array}{ccc}
4513800111 & 16.10 & 17.10 \\
\text { (EMA \#) (Date) } & \text { (01d Temp) } & \text { (New Temp) }
\end{array}
$$

Example 10. Delete Temperature Data (Hanford Designation or ElAA Codes for Well Names and Constituents)

Example with Hanford Well Designation :

DELETE 20800111

$\begin{array}{ccccc}6 & 1 & 18 & 800111 & 17.10 \\ \text { END } & & \end{array}$

Data Record Format $(12 \mathrm{Al}, \mathrm{IX}, \mathrm{F} 6.0, \mathrm{~F} 10.0)$

Data Record Explanation:

Line 1 :

$$
\begin{aligned}
\text { DELETE : Delete the Data in Line } 2 \\
2 \text { : Temperature Data Type } \\
0 \text { : Hanford Well Designation } \\
800111 \text { : Current or Latest Date in File }
\end{aligned}
$$

Line 2 :

6118 : Hanford Well Designation

800111 : Jate of Measurement

17.10 : Value to be Deleted

Line 3 : END : End of Data Set 
Example with EMA Code we11 Designation:

DELETE 21800111

$4513800111 \quad 17.10$

END

Data Record Format $(15,1 \times, F 6.0, F 10.0)$

Data Record Explanation:

Line 1 :

DELETE : Delete the Data in Line 2

2 : Temperature Data Type

1 : We11 Designation is by EMA Code

800111 : Current or Latest Date in File

Line 2 :

4513 : EMA Code for hanford Well

800111 : Date of Measurement

17.10 : Temperature Value Deleted

Line 3 : END : End of Data Set

\subsection{GENERATING GEOLOGIC DATA}

The information obtained from a well driller's log can be very useful in the study and modeling of a ground-water system. The data can be retrieved rapidly to produce listings, cross-sectional plots of an individual well, or cross-sectional plots of wells projected to a user-selected reference line (the latter runs on the PDP $11 / 55$ computer with scope and light pen capability). The procedure for storing geologic data is as follows:

1. Enter well names, coordinates and casing elevations into the data base (see Section 2.0) 
2. Determine local stratigraphy and assign ascending numbers to each stratigraphic layer. Table 3 shows the computer codes assigned to strata of the Pasco Basin used in a Hanford Study (Staff, Research and Engineering 1976)

3. Interpret driller's logs into stratigraphic layers and enter into the data base using the program WLGGEN.

Previous to January 1977, driller's logs were entered as they appeared in old $\log$ books. Each entry that existed in these books for each well was entered into the data base. Much of the notation was, however, abbreviated in order to compact the massive ammount of data. These data exist on one magnetic tape (Foreign) labeled DRILLERS LOGS (7/31/74). The data were read from cards by a program called READF, which packed the data for each well into a buffer and copied it to the magnetic tape. Each buffer size was directly related to the amount of data for the well of interest, thereby reducing the amount of wasted space on the tape. After all of the well data were transferred to magnetic tape, they could then be entered into the CIRMIS data base for rapid retrieval. A program called LGGEN.MAG was used to read the data from the magnetic tape and enter thern into the data base.

Since the original driller's logs were not interpreted by geologists, they were found to be useless in many cases because drillers on the Hanford site over the past three decades may have logged identical soil types with descriptions ranging from exact to radically different. Ceologists have since begun studying the original driller's logs and developed compacted interpreted logs based on known soir types and stratigraphy within the Hanford site. These new logs have replaced the original drillers logs in the data base. Continued studies may further update these interpretations.

\section{3 .1 Formatted Well Log Input File}

The raw data for the new interpreted well logs are stored in a formatted file on disc and tape. The name of this file is specified by the user. The first six characters may be the same as other raw data file names but the seventh and eighth characters should be unique. As an example, Hanford data files are LOGDTA10.FOR, LOGDTA11.FDR, LOGDTA12.FOR, etc. 
TABLE 3. Hanford Si te Stratigraphic Computer Code Assignments

Aeolian Sediments $\quad 100$

Touchet Silts 121

Pasco Gravels 202

Hanford Formation 203

Glaciofluviatile $\quad 204$

Palouse Soil 205

Ringold Formation 300

Ice Harbor Member 401

Levey 402

Elephant Mountain Member 403

Pamona Member 405

Selah 406

Gable Mountain Member 407

Cold Creek 408

Huntzinger Member $\quad 409$

Umatilla Member $\quad 410$

Saddle Mountains Basalt Formation 411

Mabton 412

Priest Rapids Member 413

Roza Member $\quad 414$

Frenchman Springs Member $\quad 415$

Wanapum Basalt Formation $\quad 416$

Vantage Sandstone Formation 417

Grande Ronde Basalt Formation 418

Yakima Basalt $\quad 419$

Columbia River Basalt Group 420 
The formatted $\log$ data must be stored on the CIRMIS File-Q disc in a direct access file (FRMTWLG) to be accessed by retrieval programs. FRIITWLG has pointers to each well's log data entered into the master header file (WELLHDR). This is done by a generator program called WLGGEN. This program has two modes of operation. These are 1) deleting any existing well $10 \mathrm{~g}$ entries in the CIRMIS data base and regenerating a new data base and 2) appending new wells to the existing CIRMIS well log data base.

Well log data are first entered into a formatted file for input to WLGGEN. The file format is shown in Table 4.

TABLE 4. Card Format Used for Interpreted Hanford Well Logs

CARD TYPE 1

$$
\text { Column Name Description Format } \underline{\text { Data Type }}
$$

\begin{tabular}{|c|c|c|c|c|c|}
\hline \multirow[t]{8}{*}{ Header Information } & 1 & ICARD & $\begin{array}{l}\text { Card Type Indicator } \\
\text { (ICARD = 1) }\end{array}$ & Il & Integer \\
\hline & 2 & ICONT & Not used & 11 & Integer \\
\hline & $3-14$ & WDES & WeTl Designation & $12 \mathrm{Al}$ & Byte \\
\hline & $15-20$ & DDATE & Date - drilled & $A 4, A 2$ & Real \\
\hline & $21-26$ & CASEL & Casing elevation & F6.2 & Rea 1 \\
\hline & $27-32$ & TOTDEP & Total Depth & $\mathrm{F} 6.0$ & Real \\
\hline & $33-56$ & OWN & Owners' Name & $6 A 4$ & Rea 1 \\
\hline & $57-80$ & DRL & Drillers Name & $6 \mathrm{A4}$ & Real \\
\hline
\end{tabular}

CARD TYPE 2

\begin{tabular}{|c|c|c|c|c|c|}
\hline \multirow[t]{6}{*}{ Strata Information } & 1 & ICARD & $\begin{array}{l}\text { Card Type Indicator } \\
(I C A R D=2)\end{array}$ & I1 & Integer \\
\hline & 2 & ICONT & Line Continuation Indicator & II & Integer \\
\hline & $3-14$ & WDES & Same as Card Type 1 & & \\
\hline & $15-20$ & & Bl ank & & \\
\hline & $21-26$ & BDEPTH & $\begin{array}{l}\text { Top elevation at which } \\
\text { strata begins }\end{array}$ & F6. 0 & Real \\
\hline & $27-32$ & Blank & & & \\
\hline
\end{tabular}


TABLE 4. (Contd)

$\frac{\text { Column }}{33-80} \frac{\text { Name }}{\text { STRATA Name of Strata (may exceed 12A4 }} \frac{\text { Description }}{12 \text { real words if ICONT }>1 \text { ) }}$

CARD TYPE 3 Soil Type

1 ICARD Card Type Indicator

I1

Integer (ICARD $=3$ )

2 ICONT Line Continuation Indicator I1 Integer (continuation line if ICONT

>1)

3-14 WDES Same as Card Type 1

15-20 SHADE Soil Descriptor (1eft A4,A2 Real justified\}

21-26 Blank 6X

27-32 EDEPTH Depth at which this soil F6.0 Real ends

33-80 SOILS Name of Soil (may exceed 12A4 Real 12 real words if ICONT > 1)

CARD TYPE 4 Comment

\begin{tabular}{|c|c|c|c|c|}
\hline 1 & ICARD & $\begin{array}{l}\text { Card Type Indicator } \\
\text { (ICARD }=4 \text { ) }\end{array}$ & 11 & Integer \\
\hline 2 & ICONT & $\begin{array}{l}\text { Line Continuation indicator } \\
\text { (continuation line if ICONT } \\
>1 \text { ) }\end{array}$ & 11 & Integer \\
\hline $\begin{array}{r}3-14 \\
15-26\end{array}$ & WDES & $\begin{array}{l}\text { Same as Card Type } 1 \\
\text { Blank }\end{array}$ & & \\
\hline $27-32$ & DEPTH & $\begin{array}{l}\text { Depth at which comment } \\
\text { applies }\end{array}$ & F6. 0 & Real \\
\hline $33-80$ & COMM & $\begin{array}{l}\text { Special comment (may exceed } \\
12 \text { real words if ICONT >1) }\end{array}$ & $12 \mathrm{A4}$ & Real \\
\hline
\end{tabular}


Below is a sample WLGGEN input file for one well (LOGDTA.FOR):

$\begin{array}{lllllll}11 & 6 & 38 & 15 & 120479507.56490 .0 \\ 21 & 6 & 38 & 15 & 0 & \text { GLACIOFLUVIAL SEDIMENTS } \\ 31 & 6 & 38 & 15 & \text { GS } & 35.0 \text { SANDY GRAVEL, BASALT CLASTS } \\ 31 & 6 & 38 & 15 & \text { GS } & 55.0 \text { GRAVEL, SUBANG-SUBRND F-C SAND, BASALT CLASTS } \\ 31 & 6 & 38 & 15 & \text { SMG } & 70.0 & \text { F. SUBRND SAND, OLIVE-BR SILT, GRAV } \\ 31 & 6 & 38 & 15 & \text { GSM } & 120.0 \text { F-M SANDY GRAVEL, TR. DK. YELL. BR. SILT } \\ 21 & 6 & 38 & 15 & & \text { RINGOLD FORMATION } \\ 31 & 6 & 38 & 15 & \text { MG } & 130.0 \text { GRAVELLY PALE YELL. BR. CLAY } \\ 31 & 6 & 38 & 15 & \text { GM } & 150.0 \text { CLAYEY GRAVEL, BASALT CLASTS } \\ 31 & 6 & 38 & 15 & \text { GSM } & 210.0 \text { GRAVEL, F-C ANG. SAND, SILT } \\ 31 & 6 & 38 & 15 & \text { SM } & 215.0 \text { WHITE VERY F-M SAND, SILT } \\ 31 & 6 & 38 & 15 & \text { SM } & 225.0 \text { WHITE VERY F-M SAND, SILT, PLANT FRAGS. } \\ 31 & 6 & 38 & 15 & \text { GS } & 235.0 \text { SANDY GRAVEL } \\ 31 . & 6 & 38 & 15 & \text { SM } & 250.0 \text { VERY F-M LT-GRAY SAND, SILT, FERRUGINOUS STAIN } \\ 31 & 6 & 38 & 15 & \text { GS } & 295.0 \text { GRAVEL (B CLASTS), WHITE ANG-SUBANG SAND } \\ 32 & 6 & 38 & 15 & & 295.0 \text { PLANT FRAGMENTS } \\ 31 & 6 & 38 & 15 & \text { S } & 300.0 \text { WHITE VERY F-M SAND } \\ 31 & 6 & 38 & 15 & \text { GS } & 310.0 \text { GRAVEL, WHITE ANG-SUBANG SAND } \\ 31 & 6 & 38 & 15 & & 315.0 \text { NO SAMPLE } \\ 31 & 6 & 38 & 15 & \text { S } & 320.0 \text { WHITE F-C SAND } \\ 31 & 6 & 38 & 15 & & 325.0 \text { NO SAMPLE } \\ 32 & 6 & 38 & 15 & & 340.0 \text { CLAY } \\ 31 & 6 & 38 & 15 & \text { SM } & 345.0 \text { SILTY LT-GRAY TO WHITE SAND } \\ 31 & 6 & 38 & 15 & \text { SM } & 365.0 \text { WHITE F-C ANG-SUBANG SAND, WAXY RNDED CLAY } \\ 31 & 6 & 38 & 15 & & 375.0 \text { NO SAMPLE } \\ 31 & 6 & 38 & 15 & \text { S } & 405.0 \text { ANG-SUBANG VERY F-C WHITE TO GRAY-TAN SAND } \\ 31 & 6 & 38 & 15 & \text { GS } & 415.0 \text { SANDY GRAVEL } \\ 31 & 6 & 38 & 15 & \text { M } & 425.0 \text { SILTY MED-LT-GRAY CLAY, SPLINTERY, BLOCKY } \\ 31 & 6 & 38 & 15 & \text { MS } & 445.0 \text { CLAYEY SILT, LT-GRAY, F-M SAND, BLOCKY, ANG } \\ 31 & 6 & 38 & 15 & \text { SM } & 455.0 \text { LT-GRAY VERY F-M SAND, CLAY } \\ 31 & 6 & 38 & 15 & \text { SG } & 475.0 \text { VERY F-M ANG-SUBANG WHITE SAND, TR. GRAVEL } \\ & & & & \end{array}$



$\begin{array}{llll}21 & 6 & 38 & 15\end{array}$
475.0
ELEPHANT MTN. MEMBER
$\begin{array}{lllll}31 & 6 & 38 & 15 & B\end{array}$
490.0 WEATHERED BASALT

\subsubsection{Programs for Checking Input File}

Four programs, LOGDEPTH, LOGDATES, LOGSTRATA, and LOGSRTDUP, are used to check the new log data for various types of errors as described below.

The first step is to create a file called LOGFILES.DAT which contains a list of the new log data file names (even if there is only one file). The first four characters of the new log data file name(s) must be the disc identification (DB1:, DB2:, etc.), followed by the file name. For example:

$$
\text { DB1 : LOGDTAO1. FOR. }
$$

The four programs, LOGDEPTH, LOGDATES, LOGSTRATA, and LOGSRTDUP, use characters 10 through 12 of the file name to identify the log data file when writing error information. Therefore, these characters must be unique. After LOGFILES.DAT has been created, LOGDEPTH can be run.

LOGDEPTH reads the $\log$ data $f i l e(s)$ and checks each well for depth entries that are out of order. Depths must be 1 isted from the top to the bottom of the we11. LOGDEPTH will quit running if non-numeric characters are found in numeric fields. An output file (LOG.ERR) is created which will contain any errors in depths (if any), and the last well name read if there is an error in input that stops the program. LOG.ERR will also contain the well name of the deepest well, the depth, and the file in which the data for that well may be found. A message will also be written to the user's terminal, giving the number of depth errors found (if any). LOGDEPTH must be run and erroneous data corrected until no systen errors nor "test depths out of order" occurs. When the final run has been made, then LOGDATES must be run.

LOGDATES reads the $\log$ data file(s), selects all type 11 ines (header information, a 1 in Column 1), writes columns 1 through 32 from that 1 ine and characters 10 through 12 of the file name to a file called LINEILOG.DAT. The date that the drilling was started (from columns 15 through 20) is checked for errors. If there are any embedded blanks, or the month is not equal to 1 
through 12, or the day is not equal to 1 through 31 , or the year is not equal to 40 through the current year, then the data will be written to LOGDATE.LST. There are three wells in the Hanford data base that were drilled before 1940 , and there are a few dates that are missing (blank). After LOGDATE.LST has been examined and all possible corrections have been made to the log data file(s), then LOGSTRATA must be run.

LOGSTRATA reads the $\log$ data $\mathrm{file}(\mathrm{s})$, selects all type 2 lines (strata information, a 2 in column 1) and writes the selection to LOGLINE2.DAT. After all type two 1 ines have been written to the file LOGLINE2.DAT, that file is read and the strata are summarized and written to the file STRATA.LST. STRATA.LST contains a list of each different strata, the total number of times it occurs in all of the new log data files, and the data files in which it occurs. Examining STRATA.LST may show some misspelled strata. Check any single occurrences of strata to see if it is really unique or simply misspelled. An example of an error is when GABLE MTN. appears 40 times, but GABLE MNT. appears once. Obviously MNT. in the single entry should be MTN. to match the 40 entries. After STRATA.LST has been checked and all possible corrections have been made to the $\log$ data file(s), then LOGSRTOUP must be run.

LOGSRTOUP reads the $10 \mathrm{~g}$ data file(s), writes the well name from type 1 lines (Columns 3 through 14), and characters 10 to 12 of the $10 \mathrm{~g}$ data file name in which the well name was found, to the file LOGNAMES.LST. After all names have been found, then LOGNAMES.LST is read and the names are written to six scratch files. The sorting program can only handle up to 500 wells. Therefore, for the Hanford wells, the data are separated as follows: The 199, 399,1199 , and 3099 wells are written to LOG1.DAT. The 299E 1 through $299 \mathrm{E} 27$ wells are written to LOGE1.DAT. All other 299E wells are written to LOGE28.DAT. The 299W 1 through 299W 17 wells are written to LOGWI.DAT. A1 1 other $299 \mathrm{~W}$ wells are written to LOGW18.DAT. The 699 wells are written to LOG6.DAT. The six scratch files are read and sorted separately and then combined into LOGNAMES.SRT. LOGNAMES.SRT is then read and each well name is checked against the following name to locate any duplicate names. If duplicate names are found, the well names, and characters 10 to 12 of the log data 
file(s) in which they were found, are written to WDUPCHK.LST. When a 11 duplicates (if any) are removed, or otherwise corrected, then the log data are ready to be entered into the data base.

\subsubsection{Entering Well Log Data with WLGGEN Program}

WLGGEN uses the formatted log data input file specified by the user and stores it in the CIRMIS data base on a File-Q disc in a direct access file called FRMTWLG. As each well is read in, appropriate pointers and addresses are stored in the header file WELLHDR on the File-0 disc. The procedures for doing this are described below.

1. The CIRMIS File-Q disc must be mounted.

2. The formatted file RENAMED. WEL must contain the new and old well names of all renamed wells. These names may be found in the file WELHDR.FOR. The format for RENAMED.WEL is $(1 \mathrm{X}, 12 \mathrm{Al}, 5 \mathrm{X}, 12 \mathrm{Al})$. The first 12 characters contain the new well name and the second 12 characters contain the old well name.

3A. The entire well $\mathrm{log}$ data base can be regenerated using formatted file(s) containing all of the log data using the following procedure:

\section{RUN DB1: WLGGEN}

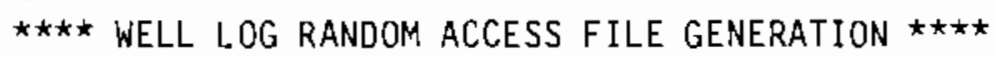

ENTER FILE Q DISC UNIT NUMBER 1

INPUT WELL LOG FILENAME DB1:LOGDTAO1.FOR

IS THIS A COMPLETE REGENERATION? ( $Y$ OR N) $\underline{Y}$

** THE WELL LOGS ARE BEING REGENERATED ** WLGGEN -- STOP

Table 3 shows the printout from WLGGEN for complete regeneration. The start block for the first well is at 0 because the data base has been completely regenerated. 
TABLE 3. Complete Regeneration Using Step 3A

$\star \star \star \star$ WELL LOG RANDOM ACCESS FILE GENERATION $\star \star \star \star ~$

"FRMTWLG"

\begin{tabular}{|c|c|c|c|c|c|}
\hline No. & $\begin{array}{l}\text { Start } \\
\text { Block }\end{array}$ & $\begin{array}{l}\text { Start } \\
\text { Word }\end{array}$ & $\begin{array}{l}\text { No. of } \\
\text { Words }\end{array}$ & $\begin{array}{c}\text { Idbit } \\
\text { (Octal) }\end{array}$ & $\begin{array}{c}\text { Well } \\
\text { Designation }\end{array}$ \\
\hline 1 & 0 & 1 & 972 & 13 & $656 \mathrm{E} 4 \mathrm{C}$ \\
\hline 2 & 4 & 1 & 1172 & 10 & $6 \quad 12$ \\
\hline
\end{tabular}

38. If well logs are to be added to the existing data base, the following procedure is followed.

RUN DB1 : WLGGEN

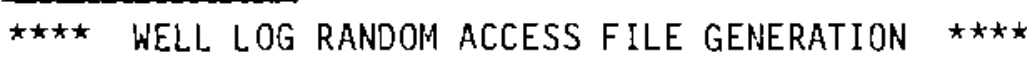

ENTER FILE Q DISC UNIT NUMBER 1

INPUT WELL LOG FILENAME DBI:LOGDTA09.FOR

IS THIS A COMPLETE REGENERATION? (Y OR N) N

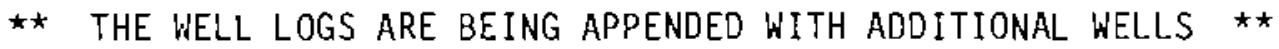

WLGGEN -- STOP

Table 4 shows the printout from WLGGEN using the "append" option. This printout shows that the start block for the first well is at 9 which was the next free location calculated from Step $2 A$.

TABLE 4. Appending Data Using Step 3B

$\star \star \star \star$ WELL LOG RANDOM ACCESS FILE GENERATION

"FRMTHL G"

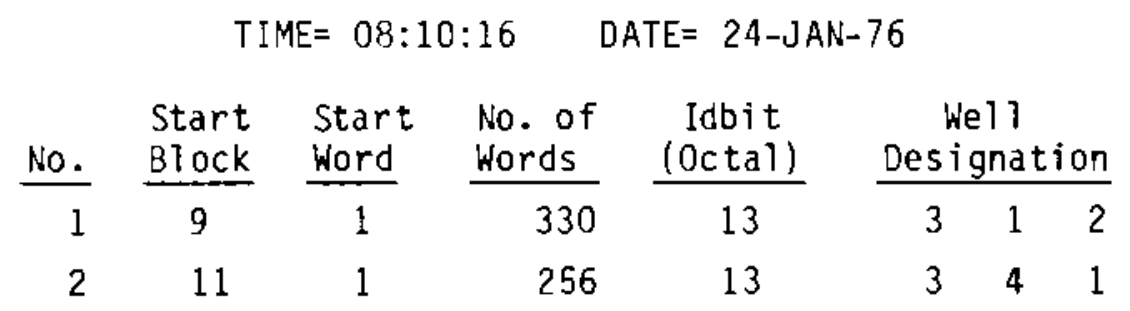


The number of blocks required for storage of each well log can be calculated from the number of words contained in each log using the following equation:

$$
\text { NBLKS }=(\text { NWORDS }) / 256+1
$$

This is done in integer notation. Using the wells shown in Table 1 the block sizes are:

$$
\begin{aligned}
& \text { Wel } 1-\text { NBLKS }=(972) / 256+1=4 \\
& \text { Wel } 12-\text { NBLKS }=(1172) / 256+1=5
\end{aligned}
$$

Data for one well may be continued across block boundaries, but no block contains data for more than one wel1. Therefore, the last block for each well may not be full.

The storage locations for each well are:

$\begin{array}{ccc}\text { Well } 1 & \frac{\text { Start Block }}{\text { End Bl ock }} \\ \text { Well } 2 & 0 & 3 \\ & 4 & 8\end{array}$

The next free location is therefore at block Number 9 .

Table 5 shows a printout if the two wells in Table 3 and the two wells in Table 4 were combined and the data base totally regenerated using Step $2 \mathrm{~A}$.

When the WLGGEN program has terminated and the line printer 1 isting has been produced (Tables 3,4 and 5), all of the log data are ready for access.

\subsection{GENERATING WELL STRUCTURE DATA}

We11 structure data consist of five types of information for each well. Each data type is of variable length. The five types are: 1) casing size and lengths, 2) perforation type and location, 3) screen size and location, 4) comments and 5) piezometer information. 
TABLE 5. Complete Regeneration Using the Four Wells in Tables 3 and 4

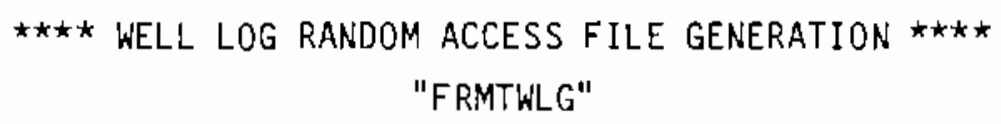

\begin{tabular}{|c|c|c|c|c|c|}
\hline No. & $\begin{array}{l}\text { Start } \\
\text { Block } \\
\end{array}$ & $\begin{array}{l}\text { Start } \\
\text { Word }\end{array}$ & $\begin{array}{l}\text { No. of } \\
\text { Words }\end{array}$ & $\begin{array}{c}\text { Idbit } \\
\text { (Octa) } \\
\end{array}$ & $\begin{array}{c}\text { Hell } \\
\text { Designation } \\
\end{array}$ \\
\hline 1 & 0 & 1 & 972 & 13 & $656 \mathrm{E} 4 \mathrm{C}$ \\
\hline 2 & 4 & 1 & 1172 & 10 & $\begin{array}{ll}6 & 12\end{array}$ \\
\hline 3 & 9 & 1 & 330 & 13 & 3 \\
\hline 4 & 11 & 1 & 256 & 13 & 4 \\
\hline
\end{tabular}

These data are entered into a file called WSTDCU.FOR. The well structures generation program, WSTGEN, reads and interprets data from WSTDCU.FOR, packs data for each well into a buffer (256 integer words), and, when the buffer is full, writes it to the direct access disc file FRMTWST. The disc address, the position in the buffer of the starting word, and the number of words for this well are written to the file WELLHDR when all data for a well have been read. A buffer (or block) may contain data for more than one well, or the data for one well may be continued across buffer (or block) boundaries.

Table 6 shows the file format for WSTDCU.FOR, and Table 7 is a key to the coded data in card type 2 of WSTDCU.FOR. 
TABLE 6. Format of WSTOCU.FOR For Well Structure Data

\begin{tabular}{|c|c|c|c|c|c|}
\hline & Column & Name & Description & Format & Data Type \\
\hline \multirow[t]{5}{*}{$\begin{array}{l}\text { CARD TYPE } 1 \\
\text { CASING INFORMATION }\end{array}$} & 1 & 11 & $\begin{array}{l}\text { Card Type Indicator } \\
(I 1=1)\end{array}$ & Il & Integer \\
\hline & 2 & I2 & $\begin{array}{l}\text { Continuation Indicator } \\
\text { (Continuation Line if } 12>1 \text { ) }\end{array}$ & 11 & Integer \\
\hline & $3-14$ & $w$ & Well Designation & $12 \mathrm{Al}$ & Byte \\
\hline & $15-18$ & DIAM & Casing Diameter $(\mathrm{ft}\rangle$ & $\mathrm{F} 4.2$ & Real \\
\hline & $19-74$ & $\operatorname{CAS}(1-8)$ & $\begin{array}{l}\text { Accumulated total feet } \\
\text { of casing. } \\
\text { (CAS may exceed } 8 \text { real } \\
\text { words if } I 2>1 \text { ) }\end{array}$ & $8 F 7.2$ & Real \\
\hline \multirow[t]{4}{*}{$\begin{array}{l}\text { CARD TYPE } 2 \\
\text { CASING PERFORATION }\end{array}$} & 1 & I1 & $\begin{array}{l}\text { Card Type Indicator } \\
(11=2)\end{array}$ & II & Integer \\
\hline & 2 & 12 & $\begin{array}{l}\text { Continuation Indicator } \\
\text { (continuation line if } I 1>1 \text { ) }\end{array}$ & 11 & Integer \\
\hline & $3-14$ & $W$ & Same as for Card Type 1 & & \\
\hline & $15-22$ & $P F(1-5)$ & $\begin{array}{l}\text { Perforation Top Depth }(\mathrm{ft}) \\
\text { Perforation Bottom Depth }(\mathrm{ft}) \\
\text { No. of Holes Per Round } \\
\text { Hole Spacing } \\
\text { Pattern of Holes } \\
\text { (PF may exceed } 5 \text { real } \\
\text { words if } I 2>1 \text { ) }\end{array}$ & $\begin{array}{l}F 8.0 \\
F 8.0 \\
F 1.0 \\
F 1.0 \\
F 1.0\end{array}$ & $\begin{array}{l}\text { Real } \\
\text { Real } \\
\text { ReaT } \\
\text { Real } \\
\text { Real }\end{array}$ \\
\hline \multirow[t]{3}{*}{$\begin{array}{l}\text { CARD TYPE } 3 \\
\text { SCREEN INFORMATION }\end{array}$} & 1 & I1 & $\begin{array}{l}\text { Card Type Indicator } \\
(I 1=3\rangle\end{array}$ & 11 & Integer \\
\hline & 2 & 12 & $\begin{array}{l}\text { Continuation Indicator } \\
\text { (continuation line if }[1>1 \text { ) }\end{array}$ & 11 & Integer \\
\hline & $3-14$ & $w$ & Same as for Card iype 1 & & \\
\hline
\end{tabular}


IABLE 6. (Contd)

CARD TYPE 4 COMMENT

CARD TYPE 5 PIEZOMETER INFORMATION$$
2
$$$$
\frac{\text { Column }}{5-37} \frac{\text { Name }}{5(1-4)}
$$$$
1
$$$$
2
$$$$
\text { 3-14 W Same as for Card Type } 1
$$$$
\text { 15-78 CH(1-16) Comments }
$$$$
\text { (CM may exceed } 16 \text { real }
$$$$
\text { words if } 12>1 \text { ) }
$$

1

II

Card Type Indicator

$(I 1=4)$

2

12

Continuation Indicator (continuation line if $\mathrm{Il}>1$ )

$\begin{array}{ll}3-14 & W \\ 15-78 & P Z(1-4)\end{array}$

Same as for Card Type 1

Piezometer Tube Designation

piezometer Length

Perforation-Top Depth ( $\mathrm{ft}$ )

Perforation-Bot Depth ( $\mathrm{ft}$ )

(PZ may exceed 4 real words if $12>1$ )

Format Data Type

F8.0 Real

F8.0 Real

F4.0 Real

F3.0 Real

I1 Integer

I1 Integer

16 A4 Rea1

I1 Integer

11 Integer

A1 Real

F5.0 Real

F5.0 Real

F5.0 Real 
TABLE 7. Key to Coded Data in WSTDCU.FOR (Computer Codes are Internal to the Program)

\begin{tabular}{|c|c|c|}
\hline Holes/Round & $\begin{array}{l}\text { Card } \\
\text { Value } \\
\end{array}$ & $\begin{array}{c}\text { Computer } \\
\text { Code } \\
\end{array}$ \\
\hline 0 & 0 & $\mathrm{BlO}$ \\
\hline 4 & 4 & B4 \\
\hline 11 & 7 & $B 27$ \\
\hline 12 & 9 & 829 \\
\hline Spacing & $\begin{array}{l}\text { Card } \\
\text { Value } \\
\end{array}$ & $\begin{array}{c}\text { Computer } \\
\text { Code } \\
\end{array}$ \\
\hline 6 in. & 0 & WDC10 \\
\hline $12 \mathrm{in.}$ & 1 & WDC1 \\
\hline $10 \mathrm{in.}$ & 2 & WDC2 \\
\hline $24 \mathrm{in.}$ & 3 & WDC 3 \\
\hline 8 in. & 4 & WDC4 \\
\hline 36 in. & 5 & WDC5 \\
\hline $9 \mathrm{in.}$ & 6 & WDC6 \\
\hline $5 \mathrm{ft}$ & 7 & WDC7 \\
\hline $18 \mathrm{in.}$ & 8 & WDC8 \\
\hline 16 in. & 9 & WDC9 \\
\hline Type of Cut & $\begin{array}{l}\text { Card } \\
\text { Value } \\
\end{array}$ & $\begin{array}{c}\text { Computer } \\
\text { Code } \\
\end{array}$ \\
\hline Regular & 0 & REG \\
\hline Staggered & 1 & STAG \\
\hline Spiral & 2 & SPIR \\
\hline
\end{tabular}




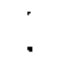




\subsection{QUARTERLY BACK-UP ACTIVITIES}

Four times per year, various programs are run to insure that disks, tapes and line printer listings of various information are updated. The following subsections describe these programs.

\subsection{CIRMIS FORMATTED OUTPUT PROGRAM (CRMFOR)}

CRMFOR creates formatted files from the CIRMIS direct access files that can be used by the regeneration programs HYDGEN, TMPGEN, and CTMGEN, to generate the data base, if necessary. CRMFOR is used primarily to provide a back-up copy of the data for quick reference.

The files used and created by CRMFOR are:

Name

WELHDRNEW.SEQ (WELLHDR ADDRESS FILE)

FILE-Q WELLHDR

FIL-E-Q FRMTHYD (HYDROGRAPH FILE)

FILE-Q FRMTTMP (TEMPERATURE FILE)

FILE-Q FRMTCTM (CONTAMINANT FILE)

FILE-Q CTMHDR (CONTAMINANT HEADER FILE) HYDRO.FOR

TEMPER.FOR

$X X M M D D Y Y . F O R$

$$
\text { Type }
$$

Access

$\begin{array}{ll}\text { FORMATTED } & \text { READ } \\ \text { RANDOM } & \text { READ } \\ \text { RANDOM } & \text { READ } \\ \text { RANDOM } & \text { READ } \\ \text { RANDOM } & \text { READ } \\ \text { RANDOM } & \text { READ } \\ \text { FORMATTED } & \text { WRITE } \\ \text { FORMATTED } & \text { WRITE } \\ \text { FORMATTED } & \text { WRITE }\end{array}$

HYDRO.FOR and TEMPER.FOR are renamed by the user after generation to HYDMMDDYY.FOR and TMPMMDDYY.FOR where MMDDYY is the current date. The $X X$ in XXMMDOYY.FOR is a constituent abbreviation (i.e., TA for total aipha), and MMDDYY is the current date. Thirty-two of these files may exist. Constituent abbreviations used by CRMFOR are shown in the following list: 


\begin{tabular}{|c|c|c|c|c|c|c|c|}
\hline EMA & $\mathrm{CON}$ & STIT & UENT & ART & & & \\
\hline CODE & $\operatorname{COD}$ & & & DRES & & & \\
\hline 112 & 1 & -- & 0) & -- & TA & -- & Total Alpha \\
\hline 111 & 2 & -- & $(2000)$ & -- & ТВ & -- & Total Beta \\
\hline 108 & 3 & -- & $(6000)$ & -- & $T R$ & -- & Tritium \\
\hline 115 & 4 & - & $(10000)$ & -- & NI & -- & Nitrate \\
\hline 121 & 5 & -- & $(14000)$ & -- & ST & -- & Strontium-90 \\
\hline 24 & 6 & -- & $(17000)$ & - & CE & -- & Cesium-137 \\
\hline 10 & 7 & -- & $\{20000\}$ & -- & $\mathrm{CO}$ & -- & Cobalt- 60 \\
\hline 104 & 8 & -- & $(23000)$ & -- & UR & -- & Urani um \\
\hline 103 & 9 & -- & $(26000)$ & -- & PL & -- & Plutoni um- 239 \\
\hline 34 & 10 & -- & $(28000)$ & -- & RU & -- & Rutheni um-106 \\
\hline 114 & 11 & -- & $(31000)$ & -- & $C R$ & -- & Chromium \\
\hline 26 & 12 & -- & $(33000)$ & - & $\mathrm{FL}$ & -- & Fluoride \\
\hline 54 & 13 & -- & $(35000)$ & -- & MA & -- & Magnesium \\
\hline 100 & 14 & -- & $(37000)$ & -- & PO & -- & Pu $239 / 240$ \\
\hline 102 & 15 & -- & $(39000)$ & - & P8 & -- & Pu 238 \\
\hline 57 & 16 & -. & $(41000)$ & -- & $\mathrm{CL}$ & -- & Chloride \\
\hline 58 & 17 & -- & $(43000)$ & -- & $C P$ & -- & Copper \\
\hline 62 & 18 & -- & $(45000)$ & -- & HD & - & Hardness \\
\hline 63 & 19 & -- & $(47000)$ & -- & SD & -- & Solids \\
\hline 116 & 20 & -- & $(49000)$ & -- & NN & -- & Nitrate Ion \\
\hline 198 & 21 & -- & $(51000)$ & -- & TC & -- & Total Organic Carbon \\
\hline 199 & 22 & -- & $(53000)$ & -- & $\mathrm{PH}$ & -- & $\mathrm{pH}$ \\
\hline 200 & 23 & -- & $(55000)$ & -- & SU & -- & Sulfate \\
\hline 201 & 24 & -- & $(57000)$ & -- & so & -- & Sodium \\
\hline 202 & 25 & -- & $(59000)$ & -- & $C A$ & -- & Calcium \\
\hline 998 & 26 & - & $(61000)$ & -- & TG & -- & Total Gamma \\
\hline 188 & 27 & -- & $(63000)$ & -- & BI & -- & Bicarbonate Ion \\
\hline 189 & 28 & -- & $(65000)$ & -- & $\mathrm{CI}$ & -- & Carbonate Ion \\
\hline 190 & 29 & -- & $(67000)$ & -- & TP & -- & Total Potassium \\
\hline 191 & 30 & -- & $(69000)$ & -- & SC & -- & Specific Conductivity \\
\hline 192 & 31 & -- & $(71000)$ & -- & $\mathrm{BN}$ & -- & Boron \\
\hline 212 & 32 & -- & $(73000)$ & -- & LA & -- & Low Alpha \\
\hline
\end{tabular}


CRMFOR may be used for analytical, water level or temperature data. The program asks for WELHDRNEW.SEQ and the desired data type. The name of the file created by CRMFOR is then written to the screen.

\subsection{PROGRAM WELNPTS FOR DATA SUMMARIES}

WELNPTS is run to provide a quick reference on the number of data points for each data type for each well stored in the data base. The following interactive run sequence is followed (underlined information is entered by the user Y:

\section{PDS $>$ RUN DB1:WELNPTS}

$08: 18: 00$

ENTER DISC \& UNIT FOR OUTPUT FILES $>$ DBI:

YOUR OUTPUT FILES ARE: DBI: CTMDAT.LST

ENTER FILE-Q DISC UNIT (i.e., DP2, DP1 or DBO) >DB1:

ENTER "?.SEQ" FILE CONTAINING WELL NAMES AND ADDRESSES > DB1:WELHDRNEW.SEQ ENTER NO. OF WELLS $(1-6000)>6000$

- -STOP

As indicated above, the output files are called CTMDAT.LST and WELNPTS.LST, and can be found on the DBl: disk if the first question is answered as shown. 


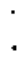

, 


\subsection{WELL DATA LISTING FOR THE HANFORD WELLS REPORT}

The technical services portion of the Ground-Water Surveillance Program periodically publishes a report called "Hanford Wells" which contains updated information on wells existing from the days before construction of the Hanford Works to the present (McGhan, Mitchell and Argo 1985). The report is used by DOE contractors needing condensed, tabular information on the location, construction and completion dates for Hanford site wells.

As new data become available from field personnel, the formatted input file to progran WELDOC is edited and renamed to DCUMNT.DAT (note that this file is not currently accessible with CIRMIS programs). After WELDOC is run to create the readable table listing (with column headings) which is used in the report, DCUMNT.DAT and the output file, DCUMNT.LST, are renamed DCUMNTYYM.DAT and DCUMNTYYM.LST, respectively, where the current year (e.g. 84) and month (e.g., A for Apri1) are substituted for YYM in both nanes. These files are copied to tape for storage. The output file may be printed out at any time for anyone who needs the most current information between report publications.

The following subsections describe in detail the required input format for DCUMNT.DAT and the procedure for running program WELDOC.

\subsection{FORMAT OF INPUT FILE TO PROGRAM WELDOC}

Data required as input to program WELDDC must exist in the following format in file DCUMNT.DAT [explanations for most items are provided in McGhan, Mitchell and Argo (1985)].

CARD TYPE 1: Well Completion Information

1-2 Card type $=1 \quad$ I2

5-16 Well name A12

17 Coordinate type $(\mathrm{D}, \mathrm{R}$, or $\mathrm{H}) \quad$ I1

18 North (N) or South (S) 
19-24 North or South coordinate I6

25 West (W) or East (E) I1

26-31 West or East coordinate I6

33-38 Casing elevation ( $\mathrm{ft}$ ) above mean sea level (e.g., 439.79 is entered as 043979) I6

41-42 Initial depth to water when drilled $(\mathrm{ft})$ I2

44-45 Casing diameter (in.) 12

47-51 Depth drilled ( $\mathrm{ft}$ ) (e.g., 63.0 is entered as 00630) I5

53-57 Depth to bottom ( $\mathrm{ft}$ ) (e.g., 65.2 is entered as 00652) I5

59-62 Date completed (e.g., June 1953 is entered as 0653) I 4

64-67 EMA number

69-73 EMA code for Rockwell sampling 14

76-82 Minimum and maximum perforated depths ( $\mathrm{ft}$ ) (e.g., 20-40) A7

87 Flag for destroyed or active wells (1 = Destroyed, $0=$ Active) Il

CARD TYPE 2: Former Designation, Rockwell File Number and Comments Column Description

Format

1-2 Card type $=2$

5-14 Former designation A10

29-48 Comments $\quad$ A20

49-65 Comments continued (appear just below first set) A17

69-74 Rockwell file number (e.g., 2-61-12 is entered as 026112) I6

CARD TYPE 3: Piezometer Information

Column Description

Format

1-2 Card type $=3$

5 Piezometer label (e.g., P, Q, R, S)

13-19 Minimum and maximum perforated depths (e.g., 20-40)

21-22 Piezometer diameter (in.) (e.g., 1.5 is entered as 15)

24-27 EMA number

29-32 Depth to bottom ( $\mathrm{ft}$ ) (e.g., 780.5 is entered as 7805) I4

35-36 Initial depth to water $(\mathrm{ft})$ 
44-47 Completion date (e.g., June 1980 is entered as 0680) I4

87 Flag for destroyed or active wells (1 = Destroyed, 0 = Active) I1

CARD TYPE 4: (to start a new page in formatted listing)

Col umn

Description

Format

1-2 Card type $=4$

7.2 CREATING LISTINGS WITH PROGRAM WELDDC

The input file, DCUMNT.DAT must exist on DBO: to run DB1:WELDDC. The following question will appear on the screen:

DO YDU WISH TO PRINT ALL HELLS? (YES OR NO)

If YES is answered, all active and destroyed wells are processed. An answer of NO will only process active wells to create the output file DCUMNT.LST. The well names will appear on the screen as the program runs to ajd in locating format errors. The program has run successfully when STOP appears on the screen. The output file DCUMNT:LST can be found on DBO: to be renamed and stored on DB1: and tape. 

PART II. USER'S MANUAL 


\subsection{INTRODUCTION}

This part of the report is directed toward those who want to retrieve data from the computerized Hanford Ground Water Data Base maintained on the PDP $11 / 70$ computer in the Geosciences Research and Engineering Department. The interactive program, MNTR, can be used to obtain listings of data on the line printer or on the screen of a terminal, create files of data on disk, or plot historical data on the Calcomp plotter. Various analytical data are printed for Pacific Northwest Laboratory (PNL) and Rockwell Hanford Operations (Rockwell) annual reports using the programs APPENA, APPENB and APPENAR. 



\subsection{DATA RETRIEVAL (MNTR)}

MNTR is the main retrieval program which utilizes appropriate subroutines to carry out the desired action. MNTR is designed to retrieve nine types of data, only five of which exist in the data base at the present time. The nine data types are listed below with an asterisk preceeding the existing five:

* 1. Hydrograph

* 2. Analytical

* 3. Hell Structure

* 4. Ceologic

5. Sieve Analysis

6. Aquifer Tests

7. Physical Properties of Soils

8. Chemical Properties of Soils

* 9. Temperature

The following sections give instructions for terminals that are hard-wired into the Ceosciences Research and Engineering Department's PDP $11 / 70$ computer, or for the Tektronics graphic terminal in the 300 Area after dialing in via modem.

Follow the procedure shown in Section 2.1 for interactive data retieval. If various data for several wells are desired, a command file may be used by answering ' $Y$ ' for the second question and entering the name of the command file when prompted (see Section 2.2). All underlined data are entered by the user after each prompt by the program. The RETURN key must be used after each entry.

\subsection{INTERACTIVE USE OF MNTR}

The user must first $\log$ onto the computer prior to running MNTR. This is done by typing the hit CTRL and $C$ keys at the same time. The user will see something like this:

IAS PROGRAM DEVELOPMENT SYSTEM VERSION 3.1

(time)

\{date\}

GEOSCIENCES DOE POP-11/70 (PNLY) 
Logging on is done as follows (password must be obtained from the data base manager) where user responses are underlined:

PDS $>$ LOGIN CIRMIS

PASSHORO

User CIRMIS UIC[351,100]TTO0: 13:33:50 29-MAY-1984

Now the user may run MNTR as follows:

PDS $\gg$ MNT

(Note: If the following does not appear after MNT, type

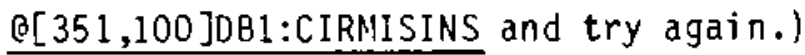

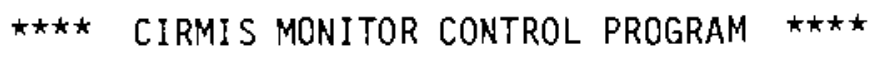

Enter File-Q Disc Unit (I.E. OB1,DB2,) >DB1

Is there a special command file? (Y or $N)>N$

Enter desired data type code

$\left(0=H Y D, 1=C T M, 2=W S T, 3=W^{\prime} L G, 10=T M P\right)>1$

Enter desired contaminant code $(1-32)>4$

Enter desired output code:

$1=$ TERMINAL LISTING

2 = LINE PRINTER LISTING

3 = DISK FILE LISTING

4 = PLOT FILE CREATEO ON DISK

$5=$ PLOT ON TERMINAL

1

Enter Well Designation (12Al) > $6 \quad 63 \quad 9$

Contaminant Data - Well No. $\begin{array}{llll}6 & 63 & 9\end{array}$

Contaminant Type - - Nitrate (mg/1)

Measurements to Date $=9$ 


\begin{tabular}{rcrcrc}
\multicolumn{1}{c}{ DATE } & VALUE & \multicolumn{1}{c}{ DATE } & VALUE & DATE & VALUE \\
\hline $9-J A N-58$ & $1.20 E+00$ & $12-F E B-58$ & $2.70 E+00$ & $13-M A R-58$ & $2.80 E+00$ \\
$10-A P R-58$ & $2.40 E+00$ & $8-M A Y-58$ & $2.20 E+00$ & $11-0 E C-58$ & $3.00 E+00$ \\
$1-A P R-59$ & $3.00 E+00$ & $1-J U L-59$ & $2.00 E+00$ & $5-D E C-62$ & $2.90 E+00$
\end{tabular}

Successful Access

00 You Want Another? ( $Y O R N)>Y$

Enter desired data type code

$(0=H Y D, 1=C T M, 2=W S T, 3=W L G, 10=T M P)>1$

Enter Oesired Contaminant Code $\{1-32\}>4$

Enter desired output code:

$1=$ TERMINAL LISTING

2 = LINE PRINTER LISTING

$3=$ DISK FILE LISTING

4 = PLOT FILE CREATEO ON OISK

5 = PLOT ON TERMINAL

3

Enter Wel1 Designation $(12 \mathrm{~A} 1)>\begin{array}{llll}6 & 63 & 9\end{array}$

Your Contaminant Output File is "CTM.FIL"

Successful Access

Do You Want Another? ( $Y$ OR N) $>\underline{Y}$

Enter desired data type code

$(0=H Y D, 1=C T M, 2=W S T, 3=W L G, 10=T M P)>1$

Enter Desired Contaminant Code $(1-32)>4$

Enter desired output code:

1 = TERMINAL LISTING

2 = LINE PRINTER LISTING

$3=$ DISK FILE LISTING

4 = PLOT FILE CREATED ON DISK

$5=$ PLOT ON TERMINAL. 


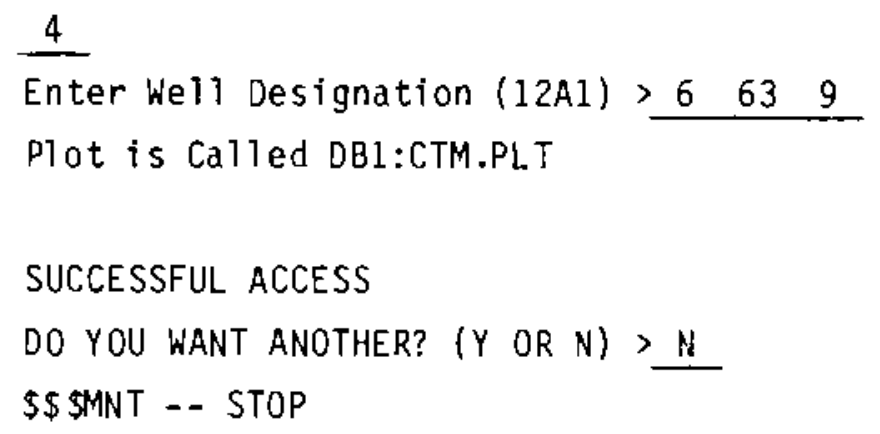

The user will end the session by typing "Logout" or "Bye" as follows:

$P D S \gg \underline{B Y E}$

User CIRMIS UIC $[351,100]$ TTOO: 13:36:25 29-MAY-1984

13:36:25 END PDS CIRMIS TTO0:

BYE

\subsection{COMMAND FILE FOR MNTR}

A command file may be used with MNTR to retrieve data for several wells automatically. The first line of a command file must contain the number of wells for which data are to be retrieved. Then each well must be listed by Hanford designation with one, two, or three lines of data below the well name to specify data type and format. The general file format is shown below:

Line 1: Number of wells

Line 2: Well name

Line 3: IDTYPE, IOTYPE, IYR1, IYR2, NCONT

Line 4: Constituent codes for desired constituents (see page 16)

Line 5: $\quad N$ (this line only required if IDTYPE $=1$ )

(Repeat lines 2 through 5 for other wells desired)

Explanation for Line 3

The following values may be used for the variables in line 3 : 


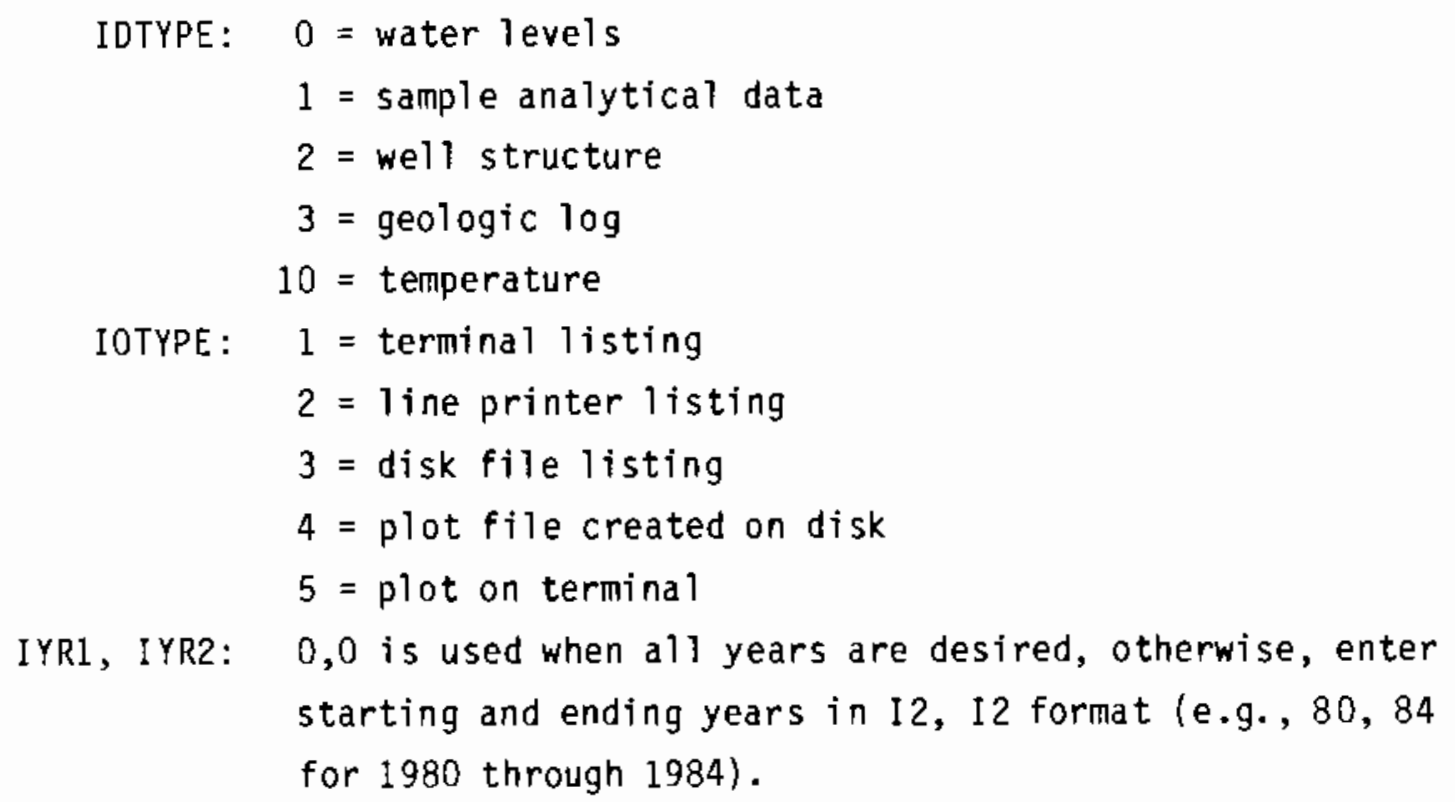

NCONT: Enter number of constituents desired if IDTYPE=1 


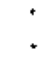

. 


\subsection{CREATING TABLES FOR ANNUAL REPORTS}

Annually, on a calendar year basis, PNL and Rockwell request formatted listings (with column headings) of various data for various wells for their annual reports. The APPENA and APPENB programs are run for PNL, and the APPENAR and APPENB programs are run for Rockwel1.

\subsection{PROGRAM APPENA}

The output from program APPENA is used as Appendix A for PNL's annual surveillance report (e.g., Eddy, Prater and Rieger 1983). The formatted output file contains minimum, maximum, and average values for selected constituents and wells for any input years. If more than 8 constituents are selected, the first 8 are printed for all wells requested, then the next 8 , etc.

The following interactive stream is followed in running APPENA, where the user's response is underlined.

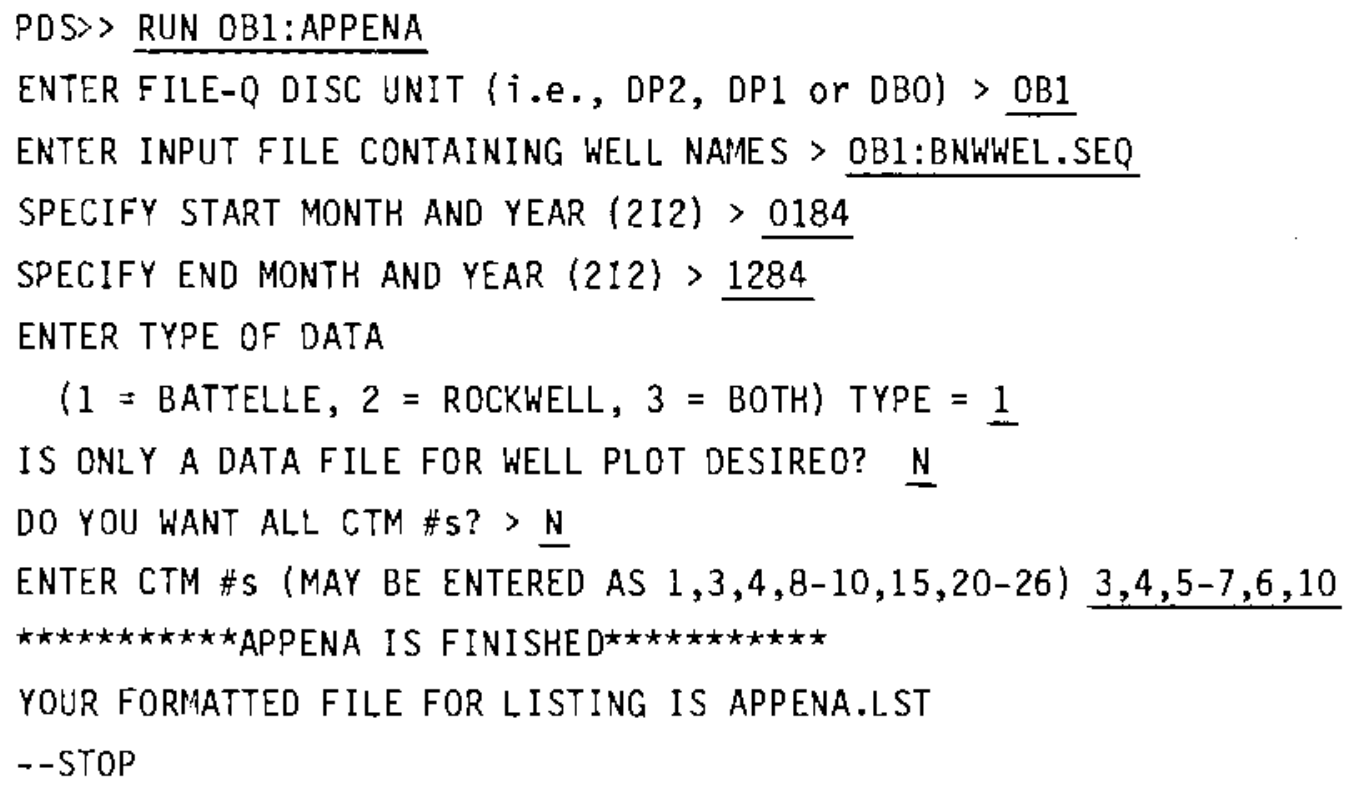

The output file, APPENA.LST on DBO:, is then printed on the line printer or letter-quality spinwriter for use in the annual report. (Use program APPENAR to create listing for Rockwell). 


\subsection{PROGRAM APPENB}

The output for program APPENB is used as Appendix 8 in PNL's annual surveillance report (e.g., Eddy, Prater and Rieger 1983). The program creates a formatted file containing all total alpha, strontium, cesium, cobalt, uranium, ruthenium, chromium, and fluoride sample analytical data stored in the data base for the wells (in the input file) and year. BNWWEL.SEQ must be available on DBO for TYPE = 1. Rockwell may request that this program be run for total beta, tritium and nitrate (TYPE = 2) and RCXHEL. SEQ must be available on DBO: for use as the input file. These files contain the list of well names to be processed.

The following interactive stream is followed to run APPENB, where the user's response is underlined.

PDS > RUN DB1:APPENB

ENTER FILE-Q DISC UNIT (i.e., DP2, DP1 OR DBO:) DB1

ENTER TYPE OF DATA

$(1$ = BATTELLE, 2 = ROCXWELL $)$ TYPE $=\underline{1}$

SPECIFY DESIRED YEAR (12) > 85

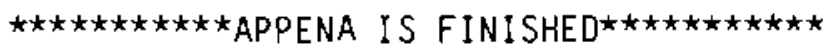

YOUR LISTING FILE IS APPENB.LST

$--S T O P$

\subsection{PROGRAM APPENAR}

The output from program APPENAR is used in annual reports written by Rockwe11. It performs the same operation as program APPENA to create a listing of minimum, maximum, and average values for selected constituents and wells (in a given input file) for any input years. The following interactive input strean is followed to run the program, where the user's response is underlined.

PDS\> RUN DB1:APPENAR

ENTER FILE-Q DISC UNIT ( 1. .e., DP2, DP1 OR DB0:) > DB1

ENTER INPUT FILE CONTAINING WELL NAMES> DB1: RCKHEL.SEQ SELECT 
(1) AVERAGE OVER ONE TIME PERIOO

(2) AVERAGE FOR EVERY YEAR DURING HISTORY

1

SPECIFY START MONTH AND YEAR $(2 \mathrm{I} 2>0184$

SPECIFY END MONTH AND YEAR (2I2) > 1284

ENTER TYPE OF OATA

$$
\text { ( } 2 \text { = ROCKWELL, } 3=\text { BOTH }) \text { TYPE }=\underline{2}
$$

IS ONLY A DATA FILE FOR WELL. PLOT DESIREO? (Y or $N$ ) $>\mathbb{N}$ DO YOU WANT ALL CTM \#S? >

ENTER CTM \#S (MAY BE ENTERED AS $1,3,4,8-10,15,20-26$ ) $\underline{3,4}$

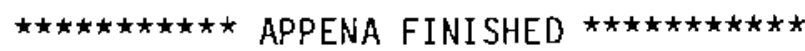

YOUR FORMATTED FILE FOR LISTING IS APPENAR.LST

--STOP 



\section{REFERENCES}

Eddy, P. A., L. S. Prater and J. T. Rieger. 1983. Ground-Water Surveillance at the Hanford Site for CY 1982. PNL-4659, Pacific Northwest Laboratory, Richtand, Washington.

Friedrichs, D. R., and R. S. Argo. 1980. CIRMIS Data System, PNL-3161, Volumes 1-4, Pacific Northwest Laboratory, Richland, Washington.

McGhan, V. L., P. J. Mitchell and R. S. Argo. 1985. Hanford Wells. PNL-5397, Pacific Northwest Laboratory, Richland, Washington.

Staff, Research and Engineering Division. 1976. Feasibility Study on Storage of Radioactive Wastes in Columbia River Basalt. ARH-ST-137, Atlantic Richfield Company, Richland, Washington. 


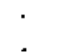


APPENDIX A

SEQUENTIAL STORAGE 
APPENDIX A

SEQUENTIAL STORAGE

Sequential storage of the well name allows 12 bytes per name and 42 names per disc sector in the well name file WELLNAM. Eight bytes are not used and are left at the end of each sector. All direct access disc files begin with a disc address of zero (0); therefore, the first 42 well names would be stored in disc sector 0 , the second 42 well names are stored in disc sector 1 , and so forth. As the name of each well is stored in the WELLNAM file, the well name, coordinates, and casing elevation are stored sequentially (one 256 word disc sector per well) in the direct access disc file WELLHDR and the well name and WELLHDR disc address is written to a formatted file WELHDRNEW. SEQ. WELHDRNEW.SEQ is used when all wells in the data base are to be searched for information and provides a rapid access to the WELLHDR file.

Figure 1 shows the storage configuration for both WELLNAM and WELLHDR. This figure also shows examples of wells (1 and 87) stored in the WELLNAM fiTe and their header blocks stored in WELLHDR.

The method of retrieval uses the following equation:

$$
\text { WHSCTR }=\text { WNSCTR } * 42+L O C-1
$$

where:

$$
\begin{aligned}
\text { LOC } & =\text { Numerial location in sector }(1 \text { to } 42) \\
\text { WNSCTR } & =\text { WELLNAM sector address }(0 \text { to } 142) \\
\text { WHSCTR } & =\text { WELLHOR sector address }(0 \text { to } 5999) .
\end{aligned}
$$

For example, the first well would have a WELLHDR disc sector address of 0 (WHSCTR : $0 * 42+1-1$ ), the 87 th well would have a WELLHDR disc sector address of $86($ WHSCTR $=2 \star 42+3-1)$.

This sequential method of storage uses the same number of disc sectors in the WELLHOR file as there are wells to be stored. If there were 87 wells to be stored in the data base, only 3 sectors (IFIX $(87 / 42+1)$ ) wouTd be used in the WELLNAM file and 87 sectors used in the WELLHDR file. If 6000 wells (maximum 
allowable) were stored in the data base then 143 sectors (IFIX $(6000 / 42+1)$ ) would be used in the WELLNAM file and 6000 sectors used in the WELLHDR file.

PATTERNED STORAGE

Patterned storage can be used if some unique patterns are detected in the assigned well designations. The storage and retrieval procedures are altered to make a more rapid search sequence. The Hanford wells show unique patterns in the first two characters of the well designation (this will be discussed later). Once a pattern has been determined, and the categories selected, the user assigns starting disc sectors (42 well names per sector) in the WELLNAM file for each category. The number of wells in each category is determined by examining the formatted data file WELHDR.FOR and this number is used to determine the number of required sectors.

The Hanford system has eight unique categories assigned to well designations. The well designation prefixes were originally 199, 299E, $299 \mathrm{~W}$, $399,699,1199,3099$, and 499; however, these prefixes were shortened to $1,2 \mathrm{E}$, $2 W, 3,6,11,30$, and 4 prior to entering into the WELHDR.FOR data file. Table 1 shows the storage configuration selected for the Hanford welis.

TABLE 1. Hanford Storage Allocation

\begin{tabular}{|c|c|c|c|c|c|c|}
\hline $\begin{array}{c}\text { Well } \\
\text { Prefix } \\
\end{array}$ & \multicolumn{3}{|c|}{$\begin{array}{l}\text { Sector } \\
\text { Range }\end{array}$} & $\begin{array}{l}\text { No. of } \\
\text { Sectors }\end{array}$ & $\begin{array}{l}\text { Wells } \\
\text { Stored }\end{array}$ & $\begin{array}{l}\text { Max. No. } \\
\text { of Wells }\end{array}$ \\
\hline 1 & 0 & to & 4 & 5 & 105 & 210 \\
\hline $2 \mathrm{E}$ & 5 & to & 34 & 30 & 555 & 1,260 \\
\hline $2 \mathrm{H}$ & 35 & to & 69 & 35 & 801 & 1,470 \\
\hline 3 & 70 & to & 74 & 5 & 37 & 210 \\
\hline 6 & 75 & to & 124 & 50 & 781 & 2,100 \\
\hline 11 & 125 & to & 129 & 5 & 105 & 210 \\
\hline 30 & 130 & to & 131 & 2 & 9 & 8 \\
\hline 4 & 132 & to & 134 & 3 & 3 & 12 \\
\hline & & Tot & als & 135 & 2,396 & 5,67 \\
\hline
\end{tabular}


It should be noted that more sectors were assigned to each category than were required to hold the names to be stored so that additional wells could be added at a later date. For example, the number of wells with a prefix of $2 \mathrm{~W}$ are 801 which would take 20 sectors (IFIX (801/42) + 1), but 35 sectors (35-69) were assigned to take care of future expansion.

The starting disc sectors for each category are shown as the first number under the tit)e "Sector Range" in Table 1 (example: starting disc sector for $2 E$ is 5$)$.

These starting disc sectors are then entered into the generator program WHDRGEN to calculate the disc sector address in WELLNAM where the well name is to be stored. The starting disc sectors are also entered into the retrieving program ZTVHDR. RTVHDR does a sequential search of the names in the WELLNAM file until a match is found for a requested well. The retrieval routine accesses one disc sector at a time and searches the 42 names for a match. If a match is not found, the next sector is accessed and searched until all sectors and names have been checked. If a match in well names has occurred, the disc sector address for WELLHDR is calculated and the pararieters retrieved according to the following equation:

$$
\text { WHSCTR }=(\text { WNSTRT + NSEC }-1) \star 42+\text { LOC }-1
$$

where:

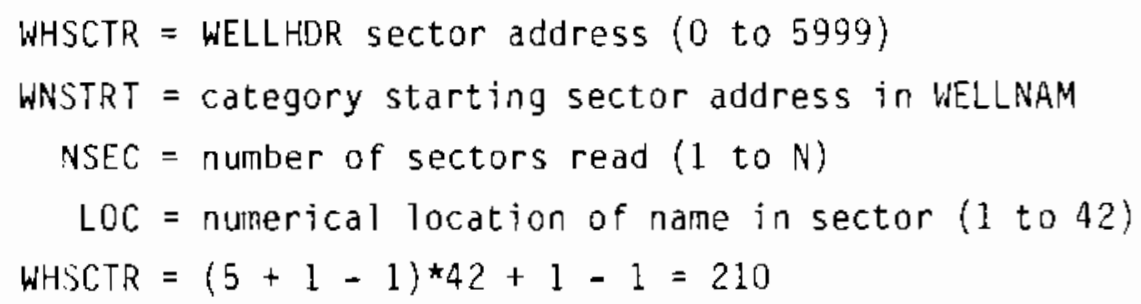


APPENDIX B

CRMSED SUBROUTINES 


\section{APPENDIX B}

\section{CRMSED SUBROUTINES}

CRMSED is not one program, but a main program with several subordinate programs. The main program, CRMSED, determines what type of data it is dealing with and what needs to be done with it, and then it calls the appropriate subprogram to carry out the details of the action. A listing of the routines comprising the CRMSED package with a very brief description of each, is given below.

\section{CIRMIS EDITING ROUTINES}

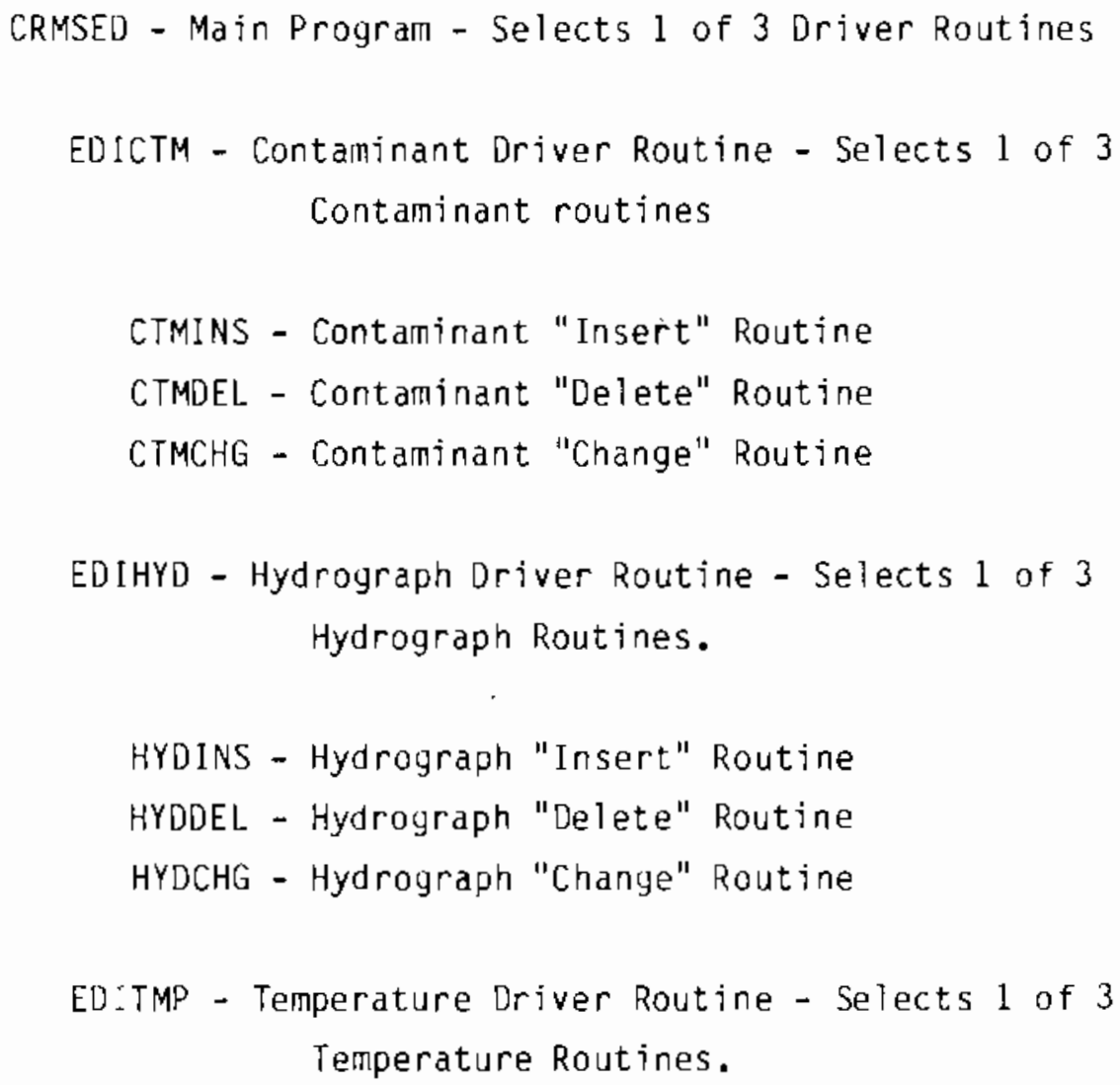


TMPINS - Temperature "Insert" Routine

TMPDEL - Temperature "Delete" Routine

TMPCHG - Temperature "Change" Routine

\author{
BSRCH - Binary Search to Locate Chronological Pasition \\ in the File for Insertion of New Data Point. \\ EMASRH - Searches "EMACODE" for Well Location When Given \\ "EMA" Number. \\ DATCHK - Checks Incoming Date to Determine if it is \\ reasonable. \\ RTVHDR - Locates Address of "WELLHDR" File for Incoming \\ Well Location.
}

CRMSED determines the action to be taken from the control record, then calls one of the three subroutines EDICTM, EDIHYD, or EDITMP, depending upon whether it's dealing with contaminant, hydrograph, or temperature data. Then, that program determines the type of action desired on the data and calls the appropriate insert, delete, or change subroutine. If the well designation is by EMA code, these programs then call EMASRH (EMA SeaRcH) to match the EMA code with the Hanford well designation. Once the Hanford well designation is found, RTVHDR is called to retrieve the header information for that well. The header information contains, among other things, the location (address) of the desired data on the disk. Those data are then read in.

Having read the date associated with the new data in the input file, the program (at this point either an "INS", "DEL", or "CHG" program) calls BSRCH to rapidly and efficiently locate where that date falls in the existing data (or outside $i t)$. If the update action is an "INSERT", the data are added to the block of data read in from disk, the appropriate "pointers" are updated, and the data are written back to disk. If the update action is a "CHANGE" or "DELETE", then BSRCH must find the corresponding date already existing in the data base. If it does, the program goes ahead and carries out the action. If 
it doesn't match the input date with an already existing date, then the program writes a warning to the user that it encountered an "INVALID DATE" and writes out the well name and input date along with an echo of the input record.

REGENERATING PROGRAMS

CTMGEN, HYDGEN, and TMPGEN are regeneration programs that read the formatted output files of CRMFDR to regenerate the data base in the event that file-Q data files are lost. A description of each program is given below:

Contaminant Regenerating Program - CTMGEN

CTMGEN will read formatted contaminant output files from CRMFOR and regenerate contaminant data. CTMGEN is used to remove empty sectors from the disc that may be caused by a large number of contaminant data deletions or to restore the data base if tape and disc backups fail or a need arises to restore the data base from some prior date.

The files used by CTMGEN are:

\begin{tabular}{|c|c|c|}
\hline Name & Type & Access \\
\hline FILE-Q WELLNAM & RANDDM & READ \\
\hline FILE-Q WELLHDR & RANDOM & READ/WRITE \\
\hline FILE-Q UPDATEHDR & RANDOM & READ/WRITE \\
\hline FILE-0 CTMHDR & RANDOM & READ/WRITE \\
\hline FILE-Q FRMTCTM & RANDOM & WRITE \\
\hline$\star$ XXMMDDYY.FOR & FORMATTED & READ \\
\hline $\begin{aligned} * X X= & \text { the } 2-\text { let } \\
& \text { (i.e., } T\end{aligned}$ & $\begin{array}{l}\text { Alation of } \\
\text { Alpha) }\end{array}$ & e contaminan \\
\hline
\end{tabular}


Enter FILE-Q disc number (A2,I1) DB1:

1. Enter contaminant file name TA031979.FOR

2. Enter contaminant code 1

3. Do you want another species? ( $Y$ or N) $Y$

Repeat 1-3 until all contaminant files are finished.

Hydrograph Regenerating Program - HYDGEN

HYDGEN will read HYDRO.FOR (formatted output file from CRMFOR) and regenerate hydrograph data. HYDGEN is used to remove empty sectors from the disc that may be caused by a large number of hydrograph data deletions, or to restore the data base if tape and disc backups fail or a need arises to restore the data base from some prior date.

The files used by HYDGEN are:

\begin{tabular}{llll}
\multicolumn{1}{c}{ Name } & \multicolumn{1}{c}{ Type } & & Access \\
${$\cline { 1 - 1 }$}$ WELLNAM $}$ & RANDOM & & READ \\
FILE-Q WELLHDR & RANDOM & & READ/WRITE \\
FILE-Q UPDATEHDR & RANDOM & & READ/WRITE \\
FILE-Q FRMTHYD & RANDOM & WRITE \\
HYDRO.FOR & FORMATTED & READ
\end{tabular}

Instructions for Operating HYDGEN

Copy the HYDMMDDYY.FOR file for the date wanted to DB1: example:

PDS〉>PIP DB1:HYDR0.FOR=DB1:HYD031979.FOR

PDS\> RUN DB1: HYDGEN (CR)

ENTER FILE-Q DISC UNIT NUMBER (A2,I1) DB1:

Temperature Regenerating Program - TMPGEN

TMPGEN will read TEMPER.FOR (formatted output file from CRMFOR) and regenerate temperature data. TMPGEN is used to remove empty sectors from the 
disc that may be caused by a large number of temperature data deletions, or to restore the data base if tape and disc backups fail or a need arises to restore the data base from some prior date.

The files used by TMPGEN are:

\begin{tabular}{lll}
\multicolumn{1}{c}{ Name } & \multicolumn{1}{c}{ TyPe } & \multicolumn{1}{c}{ ACcesS } \\
FILE-Q WELLNAM & RANDOM & READ \\
FILE-Q WELLHDR & RANDOM & READ/WRITE \\
FILE-Q UPDATEHDR & RANDOM & READ/WRITE \\
FILE-Q FRMTTMP & RANDOM & WRITE \\
TEMPER.FOR & FORMATTED & READ
\end{tabular}

Instructions for Operating TMPGEN

Copy the TMPMMDDYY.FOR file for the date wanted to DB1: example:

PDS $>$ PIP DB1:TEMPER.FOR=DB1:HYD031979.FOR

$P D S \gg$ RUN DBI:TMPGEN (CR)

ENTER FILE-Q DISC UNIT NUMBER (A2,I1) DB1: 


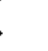


APPENDIX C

DISPOSAL/WITHDRAWAL DATA BASE 


\section{APPENDIX C}

DISPOSAL/WITHDRAWAL DATA BASE

INTRODUCTION

The disposal/withdrawal data base, FACIDB, is designed for storage and retrieval of volumetric flow rates being disposed (recharged) to and withdrawn (pumped or discharged) from the Hanford unconfined aquifer. The data can be entered as liters or gallons per month, and it is stored as cubic feet per day for use in ground-water flow models. FACIDB employs the TOTAL data base management system rather than the CIRMIS software. Data Entry Programs

There are three programs designed for interactively entering new data, updating old data, and deleting old data from the data base. They are 1) ADDFAC, for disposal or withdrawal facility name and comments; 2) UPRATE, for flow rate, source of $\mathrm{flow}$, month and year, units of rate, and comments; and 3) XYIN, for digitized latitude values along the facility perimeter. The user will be asked if 'CHANGES COMPLETE TO THIS RECORD' after inserting or updating a record. If the user does not answer "y" then no change will be made to the data base. In this way if the user has made an error, and doesn't want to perform any action he/she does not answer "y".

\section{ADDFAC - Facility Description}

ADDFAC is used to delete, insert, or update records on each facility. (i.e., crib number or pumping wel1) in the data base. It is important to note that before the user can run one of the programs to add records to the data base, a facility record must be added. In other words, the user can not add a set of $X, Y$ coordinates for $B$ Pond unt $i l B$ Pond has been added using ADDFAC. Likewise, flow rate records can not be added to $B$ Pond using UPRATE until it has been added using ADDFAC. On the other hand, a facility can not be deleted from the data base using ADDFAC until all the $X, Y$ coordinates and rate records for that facility have been deleted. All programs are designed to warn the user about this type of mistake. 


\section{UPRATE - Flow Rates}

UPRATE is used to delete, insert, or update the actual flow rate records. Pumping rates are entered as negative values. Each facility may have a number of flow rate records for a given month and year from different sources. Data that are retrieved will be a sum of all sources to that facility for a given month and year. UPRATE prompts the user for a date in the form MMDDYY, and since we are only concerned with the month and year, a day value of '01' should be used consistently (e.g., 020184 for February of 1984). Note that the default value for units is liters, so that if anything other than an ' $L$ ' or ' $G$ ' is entered, ' $L$ ' is assumed. To update or delete a rate record, the user will need to specify the facility, source, and date in order to single out exactly which record to delete. For more information on the formats of dates and numerical values when inputing the data, see Section IV, Guidelines for Interactive Updating. Comments may also be added for each flow rate record and should contain information such as reference for the data, inputs used in the water balance calculation (outside this data base) to arrive at the rate, and source description information.

\section{XYIN - Location Coordinates}

$X Y I N$ is used to delete or insert sets of $X, Y$ coordinates in longitude and latitude for a given facility. The coordinates are entered in sets of 30 on the screen at a time. The user may use the back up character (see Section IV) to back up and correct a mistake, but only on the current screen of 30 coordinates. The user may not back up to a previous screen, so if a mistake is made, the entire set must be deleted, then added again. The program will catch mistakes such as letters inadvertantly typed in place of numbers. Data Viewing Programs

\section{VALL}

VALL is used to interactively view the flow rate records for a given facility and all the comments stored with that record. The facility record is displayed at the top of the screen. The tlow rate records are viewed as one full screen at a time, in descending order of date, with the most recent records at the top of the screen. The program will pause when the screen is 
ful1. The next screen can be viewed by hitting a carriage return and so on. The user can enter the 'stop' character (see Section IV) instead of a carriage return if no more data is desired.

VRATE

VRATE is used to look at the flow rate records for a specific facility, without the associated comments. It works identically to VALi.

$\underline{T-A S K}$

T-ASK is the query 1 anguage of the TOTAL system. A T-ASK procedure has been set up to view the flow rate data excluding comments. Reports in any format may be produced. The following procedure should be used to view the data as it is stored (in cubic feet per day). The UNITS data type only indicates the units of the input data (gallons or liters per month).

After logging into the PONDEV account on the POP 11/70 computer and receiving the PDS>> prompt, type the following responses (underlined):

PDS $>$ ASK

ENTER ACCESS CODE: FACIDB

$T-A S K>$ BUILD

SELECT DATA NAMES

0 FACILITY 1 DATE

2 VALUE 3 UNITS

4 DESCRIPTION (of sOUTCe)

$\underline{0-4}$

ENTER SELECTION CRITERIA

FACILITY NE ' ' '

END (or GO to see data on the screen)

$T$-ASK $>$ OUTPUT=filename ( $i f$ data not viewed on screen)

T-ASK> GO

I-ASK> LOGOFF (to resume PDS> >) 
Subroutines for Data Retrieval with User Written Prograns

\section{$\underline{G E T X Y}$}

GETXY is used to retrieve the set of $X, Y$ coordinates stored for a given facility. It may be called from any program that supports a call statement (FORTRAN, Pascal, etc.). It is called with three (3) parameters:

FACILITY - The 12 byte facility designation.

ARRAY - An array of four byte Real numbers that is filled with coordinates by GETXY.

NUMBER - An Integer variable in which GETXY returns the number of pairs of coordinates stored for that facility.

The user provides the facility name and GETXY will return the coordinates and number of pairs of coordinates. A call to GETXY in a FORTRAN program would look like: CALL GETXY(FACILITY, ARRAY, NUMBER). The coordinate values in the ARRAY are in the order $X 1, Y 1, X 2, Y 2$, etc. If the facility passed to GETXY does not exist in the data base then an error message will be typed on the users screen, and NUMBER will be 0 . The user must make sure his/her array of real numbers is big enough to hold all the coordinates from the data base. (GETXY does not check to see if there are too many; it will return as many as it can and probably pick up some incorrect variables with the extra values.)

GETVAL

GETVAL is used to retrieve a flow rate (which is the sum of all sources for a facility) for a given month and year. It too may be called from any user written program. It uses four (4) parameters:

FACILITY - The 12 byte facility designation.

MONTH - An integer month.

YEAR - An integer year (i.e. 84)

VALUE - A four byte Real number which is the rate in cubic feet/day. 
The user provides the facility, month, and year, and GETVAL will return the rate in VALUE. A call to GETVAL in a FORTRAN program might look like: CALL GETVAL(FACILITY, MONTH, YEAR, VALUE).

If the facility passed to GETVAL does not exist in the data base, then an error message will be typed on the screen, and a VALUE of 0 is returned. If there is not a record present for the requested month and year, GETVAL will return a value of 0 .

Library Required for Compiling Codes Using Subroutines

In order to use either of these two routines, the user must 1 ink with the library which contains them from the PONDEV directory. The library is called FACTOT. For example, linking this library to a progran called TEST would require the command: LINK TEST,[356,7]FACTOT/LIB.

GUIDEL INES FOR INTERACTIVE UPDATING

Use a carriage return to answer "no" or indicate no change to any question. Entering carriage returns (CR) will eventually get you out of most processing steps.

To stop any level of updating activity, enter a dollar sign (\$) or the special stop character ([) designated for this data base. Follow it with a carriage return. The dollar sign is particularily useful when you have updated all the fields in a record you wish to update. Some prompts can only be stopped by entering a dollar sign or the stop character, followed by a carriage return.

To remove an existing value and replace it with blanks or zero, enter an asterisk $\left(^{*}\right)$ and a carriage return. Entering blanks followed by a carriage return is the same as entering just a carriage return (i.e., no action is taken).

To back up to a previous field, enter a back slash (/) and a carriage return. Successive backslashes followed by carriage returns move you backwards through the fields so you can "pick up" a field for which you were previously prompted. 
Numeric values can be entered in a variety of ways. Enter values left justified following the prompt. The program converts the number you input input the proper form for storage. Values using exponential notation (e.g., $-.123 E+01)$ can be entered using the decimal notation $(-1.23)$. Enter numeric values in the manner easiest for you. The program will make sure it is stored in the proper form and will display it on the screen in the converted form. If you enter an invalid value (eg., the letter 0 instead of the digit zero), the program will tell you it is an incorrect value and prompt you again.

Enter dates without slashes in the form MMDDYY. The program will display the date with slashes to aid readability. The program checks the month and day to see if they are valid. If they are not, it will tell you the date is improper and prompt you again. No checks are currently made for valid years.

\section{PROGRAM RATCHK FOR CHECKING INSERTED RATE VALUES}

The program RATCHK is used to retrieve and list rate values from the data base to ensure correctness of inserted data. (The T-ASK program, described above, should be used to check source descriptions. Comments sould be viewed with VALL.). The program prompts the user for the desired name of the output file, which should be no more than fifteen characters in length. The user is then prompted for the facility name exactly as it is stored in the data base. The user must then enter the units, gallons or liters, in which the data were originally entered. Next, the user is prompted to choose between retrieval of all historical values since January of 1950 or retrieval for a specified time period. The latter requires a starting month (as an integer) and a year, and both options require an ending month and year.

The program uses a CALL statement to the GETVAL subroutine from the FACTOT/LIB. GETVAL returns the values in cubic feet per day as they are stored in the data base. RATCHK converts the data to liters or gallons per month as requested earlier in the run. The data are written to the output file and echoed to the screen as the program runs. Large output files may be printed out for checking all values with raw data sheets. Note that the data returned 
by GETVAL is a summation of all sources for that month and year for the facility. The program should not be run if sources for a given month and year were input with different units. 
. 
No. of

Copies

OFFSITE

C. A. Newbil1

Battelle Project Management Division

Office of Hazardous Waste Management

HAPO Building, 4th Floor

601 Williams

Richland, WA 99352

2 DOE Technical Information Center

ONSITE

3 DOE Richland Operations of fice

R. E. Austin

D. R. Elle

H. E. Ransom

19 Pacific Northwest Laboratory

R. S. Argo

S. L. Bradymire

P. E. Bramson

C. S. Cline

D. W. Oragnich

P. A. Eddy

P. C. Hays

V. A. LesTie

P. J. Mitchell

L. S. Prater

A. E. Reisenauer

L. L. Wendell

Publishing Coordination (2)

Technical Information (5) 
:

- 